\title{
DISKONTINUITY HISTORICKÉ ARCHEOLOGIE V ČECHÁCH? NĚKOLIK POZNÁMEK KE STUDIU STŘEDOVĚKÝCH ELIT
}

\author{
JAN HASIL - DAVID NOVÁK
}

\begin{abstract}
Abstrakt: Studium středověkých elit je jedním z tradičnich témat české historické archeologie. Přesto je možno sledovat v této problematice několik výrazných tematických, chronologických i regionálních zlomů a jako nespojité lze jednoznačně charakterizovat i badatelské komunity, které se této problematice věnuji. Cílem př́spěvku je postihnout tyto diskontinuity a následně pojmenovat přičiny jejich existence v kontextu vývoje české medievistiky i veřejného diskursu. Na tuto analýzu navazuje diskusně orientovaná část, která na vybraných přkladech (akcenty výzkumu centrálních míst předpřemyslovských Čech, koncept tzv. přemyslovské domény, archeologický obraz počátků šlechty, tradice typologizaci hradů a tvrzí) poukáže na teoretické a konceptuálni limity, které před sebe česká archeologie středověkých elit dobrovolně stavěla a staví. Závěrem jsou identifikována možná východiska a navrženy kroky nutné ke zlepšení stávající situace.
\end{abstract}

Klićová slova: historická archeologie - master narrative českých dějin - teorie archeologie - středoevropský model - sídla elit.

\begin{abstract}
Discontinuities of historical archaeology in the Czech lands? Some notes on the study of the medieval elites
Abstract: The study of the medieval elites is one of the traditional subjects of Czech historical archaeology. However, several distinct theme, chronological and regional discrepancies can be traced within this field; besides, the research communities that devote themselves to these issues can be certainly characterized as disparate. This contribution seeks to identify these discontinuities and to determine their causes in the context of the development of the Czech medieval studies and in the public discourse. This analysis is followed by a discussion-based section which demonstrates on selected examples (key issues of research into central locations of pre-Přmyslid Bohemia, the concept of the so-called Premyslid domain, the archaeological image of the origins of the nobility, and the traditional typology of castles and manors) the theoretical and conceptual limits which Czech archaeology of the medieval elites has deliberately set itself, in the past and now. The paper closes with the identification of possible points of departure and with proposed steps needed to improve the existing situation.
\end{abstract}

Key words: historical archaeology - master narrative of Czech history - theory of archaeology - centralEuropean model - seats of the elites.

\section{1 Úvod}

Fórum sdružující se kolem periodika Archaeologia historica se při stoletém výročí Státního archeologického ústavu shromáždilo ke konferenci s podtitulem 100 let archeologie středověku $v \check{C} R$ a středni Evropě. Nevyřčeně tak předpokládá existenci komplexního oboru prehistorie a naproti tomu doplňkového archeologického studia období středověku. Toto studium je geneticky závislé na master narrative a systému otázek starších českých dějin, respektive obecně na historickém líčení.

Historickým narativem lze rozumět jakékoli diachronně a zpravidla kauzálně koncipované sdělení, které líčí minulé události či popisuje minulou realitu. Spadají sem tedy narace literární (tj. umělecké zpracování vyjádřené libovolnou formou včetně historiografických děl z předakademické fáze vývoje této disciplíny), prostá narace (obsažená např. v osobních i úředních dokumentech ${ }^{1}$ či vyprávěních pamětníků), ale i výsledky kritické historiografie a prríbuzných oborů a v neposlední řadě rovněž narace určená pro veřejný prostor či nejrůznější ideologie (nacionalistická líčení, marxistické učení atp.). Forma narace a ani vzájemný časový odstup popisované minulé reality a vzniku samotného př́iběhu nejsou v principu podstatné, nebot' - jak

1 Srov. pojem byrokratická próza J. Čechury (2015,27-29), který chápe úřední dokument též jako doklad sebe-stylizace novověkého úředníka. 
poukázala hermeneutika druhé poloviny 20 . století - způsob i rozsah porozumění obsahu narativu nejsou závislé jen na intencích jeho tvůrce, nýbrž do značné míry na předznalosti a zkušenosti konkrétního př́jemce. ${ }^{2}$

Česká středověká archeologie jako př́ijemce historického narativu vytvořila uzavřenou obálku arbitrárně zvolených témat, která se stala součástí diskursu (čímž stanovila i množinu témat vyloučených). Jim pak po generace podřizovala sběr a třídění pramenů, takže u mnoha jejích kategorií - mnohdy souvisejících s otázkou výzkumu zaměřeného na elity a jejich sídla - je dnes sotva možné založit diskusi s historickým narativem. Archeologie neutváří jeho alternativu spektrem současných výzkumných otázek, a tedy ani výběrem preferovaných pramenů, které využívá pro hledání odpovědí. Problémem tak primárně není nedostupnost či nízká míra utříděnosti pramenné báze, ale paradigma badatelské komunity, kvůli kterému její podstatná část zůstává nevyužita, nebo dokonce nezpracována. Na jedné straně byl podobný arbitrární výběr témat a pramenů zcela legitimní v obdobích, kdy archeologie vstupovala do pro ni zcela nového prostředí (doba formulování slovanské archeologie v 19. století, formování archeologie mladšího stř̌edověku v 60 . letech 20. století atp.), nicméně se podle našeho názoru nejedná o trvale udržitelný základ paradigmatu historické archeologie. Současný výsledek tohoto př́stupu totiž pokládáme za kontroverzní: na jedné straně česká archeologie středověku disponuje propracovaným výkladovým rámcem, který jí umožnil průběžně tematizovat převážnou část jevů, s nimiž se setkává, respektive kterými se aktivně chce zabývat. Problémem však je nepřenositelnost prŕstupu do jiných regionů či období a také vnitřní nestabilita - interpretace historických narací představuje iterativní a nikdy nekončící proces, a tak na nich z principu nelze budovat stabilní oborové paradigma.

Hypoteticky vzato, pokud by například zakladatelé české archeologie mladšího středověku $\mathrm{z}$ generace M. Richtera a Z. Smetánky formulovali svůj program v návaznosti na otázky dnešního dějepisectví, hráli bychom, nepochybně s totožnými kartami v rukách, zcela jinou hru. Reflektovali bychom nejspíše témata jako dějiny mentalit, studium skupinové reprezentace, gender atp. Současný výkladový rámec proto nyní vůbec nepokrývá nejstarší období raného středověku, tedy čas nástupu historických společností ve střední Evropě, který je podle některých autorů zlomový pro společenské uspořádání (srov. Květina et al. 2015). Podobně pak novověk není pojatý jako období růstu komplexity společnosti a s ní spojených otázek, ale jako období, kdy vyznívají ta témata archeologie středověku, která ještě jsou alespoň rámcově relevantní. Takový př́stup pak logicky zcela vylučuje archeologické studium moderní společnosti jako smysluplné badatelské pole.

\section{0 přirozené povaze dvou blízkých oborů}

Úskalím historické archeologie je zdánlivá komplementarita různého typu pramenů (písemných i hmotných), které domněle utvářejí celistvý obraz skutečnosti. Každá z těchto částí výzkumného materiálu však vyžaduje užití zcela odlišných analytických metod, které jsou ukotveny v jiné oborové teorii. Stejně jako nelze př́ímočaře zaměňovat místní označení s archeologickým areálem, nelze přímočaře mísit archeologické události s popisovanými událostmi historickými. Je symptomatické, že mnoho archeologů se považuje zároveň za historiky, což zpravidla neplatí obráceně. Naopak je paradoxem, že jedinou syntézu kontinuálně pokrývající artefaktuální vývoj na území Čech koncipoval a úspěšně završil historik - Josef Petráň (Petráň et al. 1985-1997), a to nota bene v období, kdy nebylo možno svobodně a kriticky pracovat s historickým vyprávěním.

Dělicí čára mezi strukturálním a událostním př́stupem bezesporu neběží po rozhraní jednotlivých pramenných kategorií. Dávno neplatí pozitivistické zařazení archeologa jako správce sbírek artefaktů a historika jako znalce archiválií. Kým by pak byli odborníci zabývající se

\footnotetext{
2 Tak např. H.-G. Gadamer (2010, 245): „V pravdě dějiny nepatři nám, nýbrž my patříme dějinám. Dávno předtím, než se zpětným zamyšlením dobereme rozuméni sobě samým, si samožrejmým způsobem rozumíme v rodině, společnosti a státě, v nichž žijeme. Ohnisko subjektivity je pokřivené zrcadlo. Sebezamyšleni individua je jen pableskováním v uzavřeném okruhu dějinného života. Proto jsou předsudky jednotlivce mnohem spiše než jeho vlastnimi úsudky dějinnou skutečnosti jeho byti.“ A dále M. Foucault (1997, 24; překlad JH): „Je to tedy kniha, která tomu, kdo ji píše, a stejně tak tomu, kdo ji čte, slouži jako zkušenost, mnohem spiše než zjištění historické pravdy."
} 
zpracováním ekofaktů získaných archeologickým výzkumem? Ani na úrovni otázek nelze hledat definující kritérium, nebot' historie i archeologie jsou schopny svébytně uchopit totožné problémy historické společnosti. Volba padá teprve s aplikovaným teoretickým přistupem, který pomáhá rozhodnout o výběru a metodě zpracování konkrétních pramenů. Tím je teprve předurčena i forma výstupu archeologické či historické syntézy.

Zatímco pro historickou vědu je tvorba nového narativu přirozeným způsobem oborové komunikace, který odpovídá její tisícileté tradici literární subdisciplíny, archeologie studuje především strukturní či cyklické aspekty minulosti, k jejichž vyjádření není diachronní narace vždy optimální formou (Vašíček 2006, 94-122). Protože však způsob formulace mnoha badatelských otázek středověké archeologie je ovlivněn či přímo převzat z historiografického diskursu, směřuje potom i způsob jejich zodpovězení k př́slušné narativní formě, čímž historická archeologie - i její konkrétní protagonisté - ztrácí svou oborovou identitu. ${ }^{3}$ Jak nedávno upozornila S. Grunwald na př́íkladu archeologie hradišt' v Sasku, tuto tendenci umocňuje fakt, že důležitou složku soutěže o prestiž, zdroje i legitimitu oboru představuje přiřazení výsledků archeologického bádání $\mathrm{k}$ narativům budujícím kolektivní identitu společnosti. Protože ale tyto identity musejí být vázány k jasně definovaným významům (obvykle sociálním či chronologickým entitám), archeologie se jim ,z oportunnich důvodư“ podřizuje (Grunwald 2019, zejm. 22-24, 219), přestože svými prostředky není schopna rekonstruovat ani minulé skupinové identity (Brather 2004, zejm. 99-103), ani uchopit historický čas - sleduje pouze stopy konkrétních událostí ve formě statických artefaktů (Neustupný 2010, 185-199).

Pokud bude historická archeologie vybavena teoretickými nástroji ke kultivaci svého oborového diskursu, ${ }^{4}$ bude snáze směřovat ke strukturalistickému pojetí svých témat, výstupů a komunikačních strategií. ${ }^{5}$ Průběžná kultivace paradigmatu však představuje důležitý úkol i vzhledem $\mathrm{k}$ dalším oborům než pouze $\mathrm{k}$ historiografii, zejména $\mathrm{k}$ supra-disciplínám a střešním oborům (např. kastelologie, montanistika nebo garbologie), ${ }^{6}$ které neformulují vlastní teorii a metodu, krátkodobě působí jako jakési katalyzátory rozvoje poznání, ale z dlouhodobého hlediska činí obrysy historické archeologie méně a méně zřetelnými.

Archeologie sídel elit (a synekdochicky i kastelologie diskutovaná dále v prríspěvku) představuje jedno z klíčových témat historické archeologie v Čechách, a proto na něm lze většinu uvedených úskalí demonstrovat na konkrétních príkladech. V této problematice je možno sledovat několik výrazných tematických, chronologických i regionálních zlomů a jako nespojité lze jednoznačně charakterizovat i badatelské komunity, které se jí věnují. Proto v následujících kapitolách využijeme př́kladů právě z této oblasti výzkumu přelomu raného a vrcholného středověku.

\section{Archeologie v zajetí cizího příběhu}

Pro české středověké prostředí je příznačná výjimečná kontinuita a téměř výhradní exkluzivita master narrative, který se začal odvíjet nejpozději na stránkách Kosmovy kroniky. Ten byl průběžně rozvíjen středověkým, novověkým i moderním dějepisectvím a nikdy nečelil rovnocenné

\footnotetext{
3 Charakteristickým př́ikladem jsou různé př́ležitostné stati o vztahu historiografie a archeologie, v nichž je výklad stavěn vesměs od perspektivy (pramenné, teoretické, metodické) historické, přičemž je lhostejno, zda autorem textu je historik (Třeštík 2001a), či archeolog (Klápště 2003; Profantová-Profant 2003).

4 Srov. strukturalistické akcenty tzv. freiburské školy historické archeologie (výběrově Brather 2004; Steuer 1997; Brather-Geuenich-Huth 2009) i polemická stanoviska jejích kritiků (charakteristicky Bierbrauer 2004), kteři nadřazují výkladový potenciál narativu analytickým přednostem strukturálních koncepcí.

5 Narativní princip je jistě jedním z obvyklých a možných způsobů, jimiž archeologie může předkládat a „překládat“ své výsledky širší odborné komunitě či veřejnosti, a nelze pochybovat o tom, že špičkové odborné práce, které jsou na něm založené, mohou dosahovat i nezpochybnitelných literárních kvalit (charakteristicky Klápště 2005, ze zahraničních studií např. Stephan 2010). Tím ovšem není vyloučeno hledání takových způsobů sdělení, které jsou strukturovány např́iklad podle prostorového principu a o průběžný narativ naprosto neusilují, o čemž v českém a moravském prostředí svědčí specialisty i veřejností neobyčejně vstřícně přijaté publikační projekty z nedávné doby (Kuna et al. 2014; Boháčová-Podliska et al. 2015; Tomášek et al. 2015). Takovému způsobu komunikace ostatně svědčí také rodící se digitální korpusy založené na vnitřní provázanosti a jasné struktuře (srov. http://www.aiscr.cz/).

6 Do ranku těchto supra-disciplín spadá ostatně i samotná medievistika, je-li chápána jako tzv. totálni či komplexní (Smetánka 2015, 110; J. Klápště prostřednictvím Štefan 2019, 127); pohříchu se však tento obrat vyskytuje na stránkách memoárového, a nikoli teoretického spektra archeologické literatury.
} 
konkurující koncepci výkladu českých dějin. ${ }^{7} \mathrm{~V}$ rámci středoevropského prostoru se jedná o zcela jedinečnou situaci (srov. situaci v říšském prostředí, kde žánr národních kronik nastupuje s výrazným zpožděním a je předcházen institucionálními kronikami či panovnickými gesty). Jde o doklad mimořádné stability české státnosti a s ní související kontinuity sdíleného vnímání dějin - včetně prostoru, v němž se odehrávají. Na strukturální úrovni se patrně stejný fenomén projevuje nebývalou stabilitou zemských hranic, ale také centrálních míst, mezi nimiž zcela dominuje Praha, a to jako prominentní objekt narativu i archeologicky vnímaný areál.

Problém však přirozeně nastává, pokud se pohybujeme mimo rámec tohoto diskursu. V něm samozřejmě nenacházejí místo sídla elit předpřemyslovského období (7. až první třetina 9. století), jejichž existenci dokládá zjevná komplexita tehdejší společnosti, zprávy karolinské analistiky a v posledních letech prudce přibývající nálezy význačných kovových artefaktů převážně cizí, západní a především východní, byzantsko-avarské provenience. Česká archeologie v současné době disponuje poznatky o několika výrazných centrech, kam se tyto nálezy v počtu vysokých desítek kusů soustředí (Rubín, okr. Louny; Budeč, okr. Kladno; Kal, okr. Jičín; Libice nad Cidlinou, okr. Nymburk; Hostim, okr. Beroun a především Tismice, okr. Kolín). Zároveň je však nutno konstatovat, že s přibývajícím množstvím artefaktů, jež byly získány v ploše těchto hradišt' i v jejich zázemí (Hasil-Profantová-Levá 2020, tab. 1), se stírá představa jejich exkluzivity.

Vzhledem k množství nových nálezů těchto artefaktů, a především vzhledem k prvním dokladům produkce jejich „spotřebních typů“ na našem území (Tismice - Profantová v tisku; Břeclav-Lány - sdělení J. Macháčka) definitivně padá i narativ o kočujících elitách budovaný okolo anekdotických líčení kroniky tzv. Fredegara a Povesti vremených let. ${ }^{8}$ Kvalitativní analýza naopak ukazuje na přítomnost komunit, které měly přístup ke špičkovým, uměleckořemeslně vysoce hodnotným importům. Ty nalézáme ve výšinných polohách lokalizovaných při okraji sídelní oikumeny (viz obr. 1), jež však nejsou od zmiňovaných center př́iliš geograficky vzdálené (Svatý Jan pod Skalou, okr. Beroun; Mořinka, okr. Beroun; Praha-Radotín/Kosoř, okr. Praha-západ - Profantová 2017; popř. také hradiště Havraník, okr. Kolín - Profantová 2000). Výzkum raně středověkého využití těchto prominentních poloh je dosud na téměř nulovém bodě, přesto je možno hypoteticky hovořit o zformování dvou odlišných sídelních forem - nadkomunitního areálu (hradiště či hrazeného sídliště) a samostatného sídla elity, zahrnujícího hospodářské, reprezentativní a rezidenční zázemí, a to o půl tisíciletí dříve, než ji ve vrcholně středověké krajině vyjádřily kategorie města a vrchnostenského sídla. Otevření podobné debaty je ostatně potenciálně př́ínosné i pro mladší období raného středověku (viz problematiku pojmu raně středověký hrad - charakteristicky Boháčová et al. 2003, zejm. 471-475).

Jiný typický př́klad interakce mezi historickým narativem a studiem struktur nabízí notoricky známý interpretační model rané fáze středočeského přemyslovského panství, tzv. přemyslovská doména. J. Sláma jej zformuloval po delší diskusi (zejména se Z. Váňou) v polovině 80. let v éře syntézy poválečného výzkumu hradišt' (Šolle 1984; Sláma 1986; 1989). Jedná se o kongeniální vstup do roviny vyprávěcí i strukturní, protože model zároveň vykrývá Kosmovu odmlku o vládě prvních tř́i přemyslovských generací a současně konceptualizuje rozsáhlé výsledky intenzivního studia hradišt' zmíněných nejstaršími českými legendami. Problematický je však „druhý život“ tohoto učeneckého konstruktu, který pro svou sílu, invenčnost i charisma tvůrce obratem povýšil na historický fakt. I přes kritiku L. Varadzina (2010), který revidoval chronologické zařazení „uznaných“ i „potenciálních“ komponent tohoto útvaru, vystihuje většinové stanovisko vnitřně zcela rozporuplný citát A. Bartoškové $(2014,16)$ :,(...) o existenci středočeské přemyslovské domény není sporu, ta je nepochybná, pochybovat však lze o jejím rozsahu (...) a také o časovém intervalu jejího utvárení." Tento výrok naznačuje, jak nestabilní jsou zdánlivě pevné opory dosud dominantní interpretace.

7 K otázce kontinuity kosmovského master narrative viz Hasil-van Rensvoude 2019.

8 Literární jádro těchto líčení, která zřejmě vůbec nebyla založena na znalosti poměrů v konkrétním prostoru a čase, v daném př́ípadě rozpoznali R. Collins $(2008,112)$, resp. D. Třeštík $(2001,26)$ 


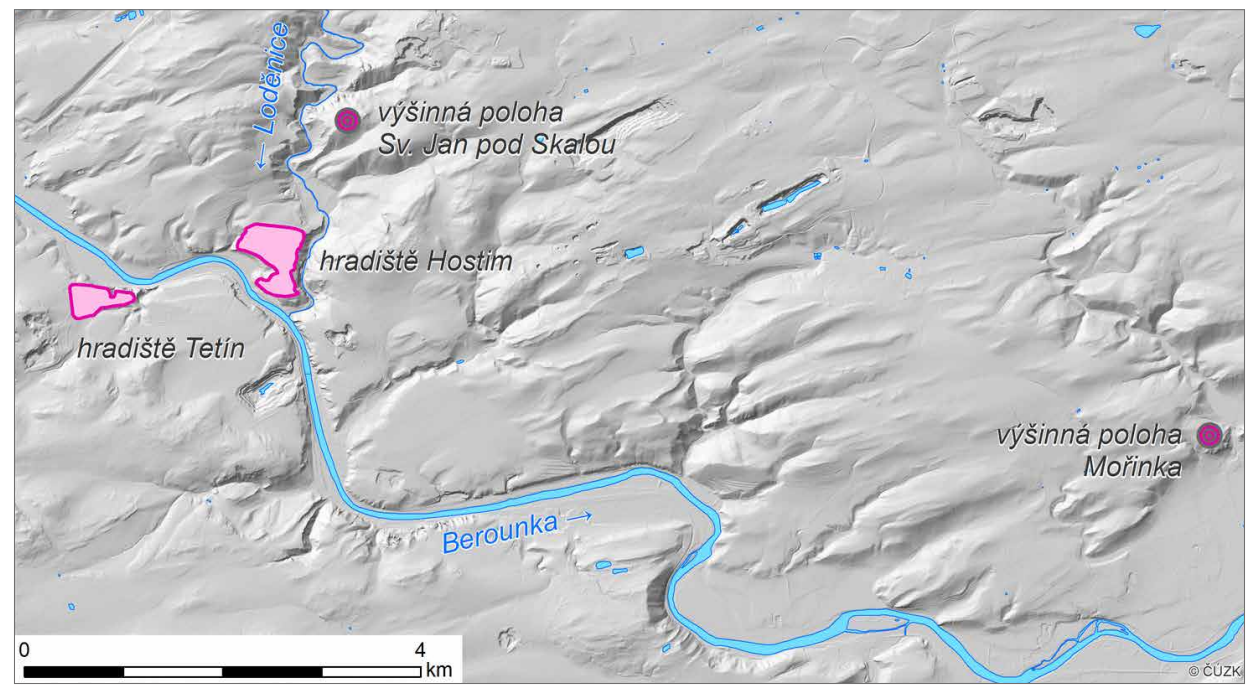

Obr. 1. Raně středověká sídla elit při dolním toku Berounky. Nejstarší chronologickou komponentu představuje hradiště Hostim jako regionální nadkomunitní centrum, jehož funkce snad doplňovala stanoviště na výšinných polohách nad Svatým Janem pod Skalou a Mořinkou. Centrální funkce i explicitní doklady přítomnosti elity raného přemyslovského státu se v průběhu raného středověku přesouvají na hradiště Tetín.

Abb. 1. Frühmittelalterliche Sitze von Eliten am Unterlauf des Flusses Berounka. Die älteste chronologische Komponente stellt der Burgwall Hostim als regionales übergemeinschaftliches Zentrum dar, dessen Funktion wohl von Standorten in Höhenlagen oberhalb von Svatý Jan pod Skalou und Mořinka ergänzt wurde. Die zentrale Funktion und auch explizite Belege für die Präsenz von Eliten des frühen Přemyslidenstaates haben sich im Laufe des frühen Mittelalters auf den Burgwall Tetín verlagert.

Za hranou pozornosti naopak zůstává celá řada jiných, velmi podstatných otázek, například nezbytná proměna osídlení v zázemí nově vznikajících přemyslovských center. Chybí zde představa o jejich fungování ve sféře „veřejné“ i jako přímého hospodářského zázemí nastupující dynastie. Jak prokázaly výzkumy „periferních“ pražských hradišt' v Klecanech, Královicích a Vinoři, ${ }^{9}$ chybí také vysvětlení jejich pozdějšího vývoje a proměn jejich střediskové úlohy (viz obr. 2). Nejzávažnější je ale nárůst nerovnováhy sběru dat v rámci sítě českých hradišt'; zatímco na hradiště s pravěkou komponentou připadá přibližně vyrovnaný počet evidovaných terénních akcí, na jediné procento českých hradišt', jež zmiňují nejstarší písemné památky, připadá celých deset procent (!) terénního úsilí věnovaného výzkumu všech hradišt' (viz obr. 3). Přitom je třeba zohlednit zřejmý, ale stěží kvantifikovatelný fakt, že se zde bavíme o dlouhodobých a nákladných výzkumech Pražského hradu, Vyšehradu, Budče, Levého Hradce, Staré Boleslavi či Kouřimi. Vyzdvihování některých lokalit, která má zjevné nearcheologické zdůvodnění, pak samozřejmě vede k výraznému podcenění výzkumu regionů mimo střední Čechy a regionalizace jako takové.

\section{Terra incognita - za prostorovou hranicí dějinné narace}

Prapřičiny útlumu regionálně zaměřeného studia sídel středověkých elit je opět možno sledovat v obecném vývoji společnosti. Jako první ztratily své regionální historiografické a archeologické komunity pohraniční oblasti, a to v důsledku vyhnání německého obyvatelstva po roce 1945 . Signifikantní je v tomto směru prŕíklad Chebska, tedy regionu, který historicky nebyl součástí

9 „Perifernost“ těchto součástí sídelní sítě raně přemyslovských středních Čech je ovšem dána výhradně jejich absencí v raně středověkých písemných pramenech, a tedy opět v historickém narativu; z hlediska archeologického projevu jsou však tyto lokality plně srovnatelné s ostatními, ,prominentními“ lokalitami - viz Profantová 2010-2015; Hasil-Štefan 2018. 


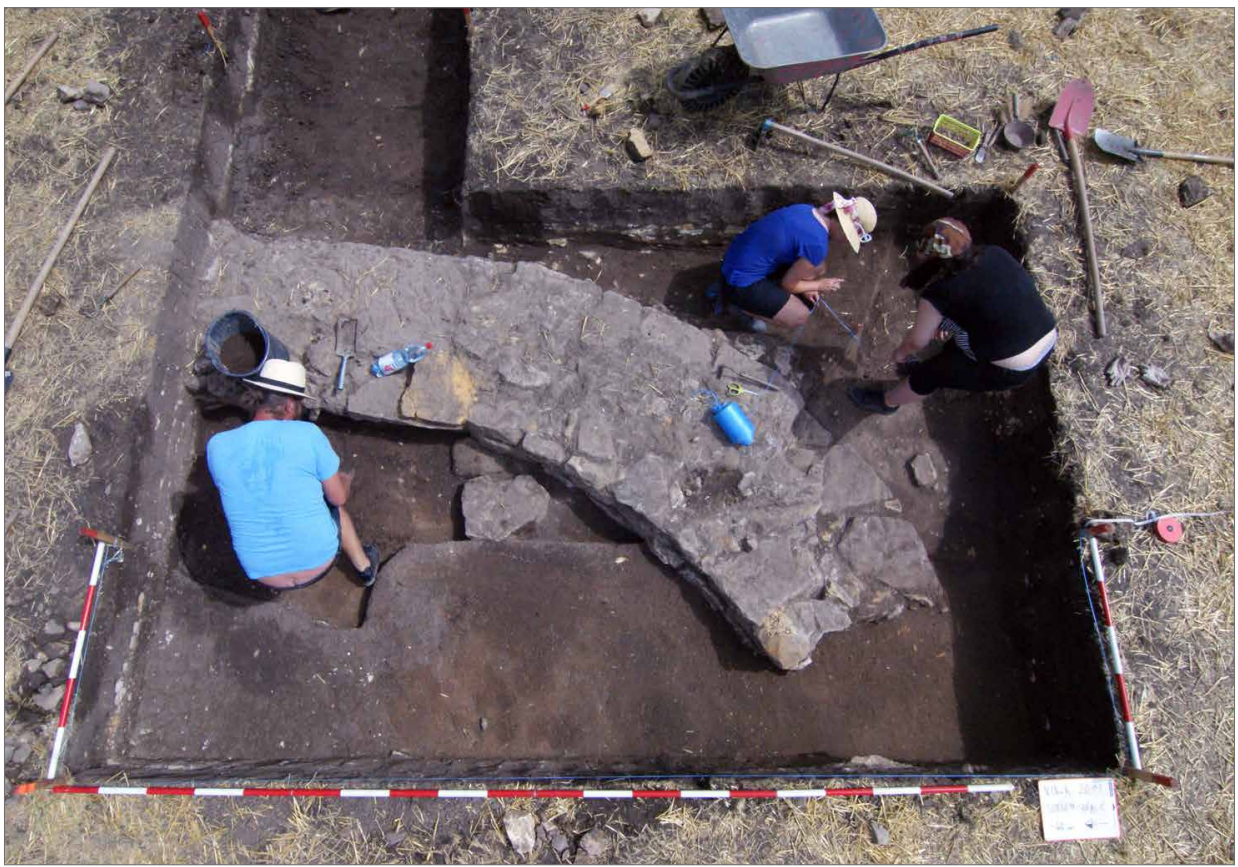

Obr. 2. Momentka z výzkumu FF UK roku 2019 na raně přemyslovském hradišti v Praze-Vinoři. Zdiva nově objeveného vrcholně stř̌edověkého tvrziště v areálu raně stř̌edověkého hradiště ukazují na složitý vývoj formy a funkcí tohoto elitního sídla. Foto J. Hasil.

Abb. 2. Momentaufnahme der 2019 von der Phil. Fak. der Karls-Universität auf einem frühpřemyslidischen Burgwall in PragVinoř durchgeführten Grabung. Die Mauerwerke des im Areal des frühmittelalterlichen Burgwalls neu entdeckten hochmittelalterlichen Adelssitzes weisen auf die komplizierte Entwicklung von Form und Funktion dieses Elitensitzes hin. Foto J. Hasil.

českého království a který ve středověku prodělal výrazně odlišný kulturní i společenský vývoj (souhrnně Hasil 2018). Starší německé bádání si bylo této svébytnosti dobře vědomo. Poválečné, téměř padesát let trvající úsilí českých badatelů o vřazení Chebska do struktury centristického výkladu českých středověkých dějin se ale nutně muselo potkat s nezdarem. Diskuse o lokálních strukturách elit a jejich sídel, vedená po roce 1989 v kontextu vývoje sousedních regionů, pak přirozeně vedla k obnově dnes zřejmě nejživotnějšího regionálního diskursu studia sídel elit, na jehož aktualizaci mají klíčový podíl F. Kubů, T. Karel, V. Knoll a T. Klír. ${ }^{10}$

Širokým uplatněním centristické koncepce starších českých dějin, které zejména pod vlivem D. Třeštíka potlačilo regionalizaci Čech předpřemyslovského a raného přemyslovského období, došlo k upozadění regionálních narativů domnělé zlické či lučanské oblasti, které se pravidelně uplatňovaly od dob humanismu hluboko do druhé poloviny 20. století. Tím opadl i tradiční archeologický zájem o související centrální místa mimo vliv Přemyslovců. Jejich osud následovaly i historické kraje, zejména ty, které byly v integraci do přemyslovského státu poněkud opožděné (Prácheň, Plzeňsko). ${ }^{11}$

Ke studiu regionalizace struktur však lze využít i pramen, který je jinak přirozeně pokládán za klíčový zdroj líčení starších českých dějin, Kosmovu Kroniku Čechů. Pokud záměrně zcela odložíme diachronní vnímání jejího textu a zaměříme se na synchronní vnímání jejích

10 Srov. tradicionalistické, tedy „kastelologické“ pojetí téže problematiky z pera J. Úlovce (1998).

11 Posledním badatelem, který se systematicky problematice regionalizace raně středověkých Čech i tehdejších sídel elit seriózně věnoval, byl R. Turek (zejm. 1957; finálně 1982). Rozvoj této problematiky ve studiích badatelů, kteři emigrovali po roce 1968 (Graus 1980 ; Karbusický 1980), již nikdy nebyl „domáci““ medievistickou scénou reflektován. 


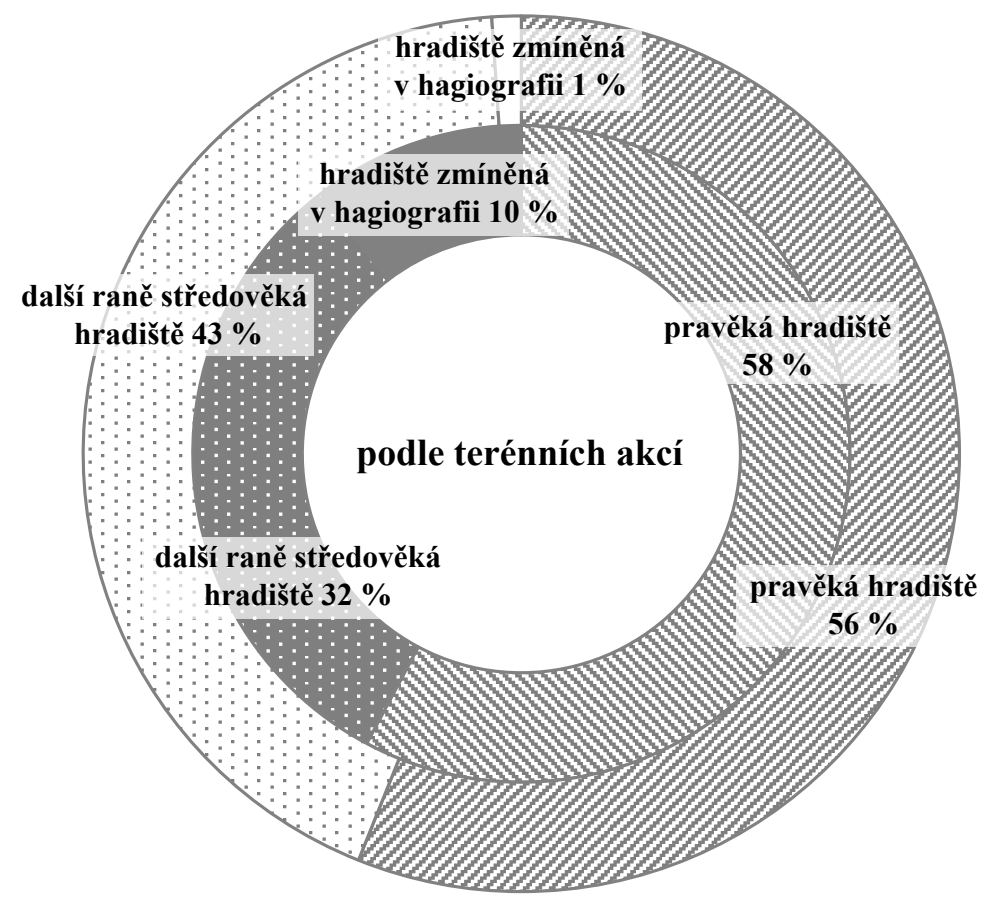

\section{podle chronologické komponenty/ zastoupení v nejstarší legendistice}

Obr. 3. Graf zobrazující rozložení archeologické terénní aktivity v rámci sítě hradišt' v Čechách podle chronologické komponenty a evidence $v$ nejstarší české hagiografii. Je zřejmé, že nejmenší (1 \%), dílem nahodilé výseči hradišt' historicky spojených s prvními příslušníky přemyslovského rodu se dostává zhruba desetinásobné pozornosti v porovnání s ostatními hradišti v Čechách. Podle AMČR, stav 2016.

Abb. 3. Diagramm mit Darstellung der Verteilung der archäologischen Geländeaktivitäten im Rahmen des Burgwallnetzwerks in Böhmen entsprechend der chronologischen Komponente und Erfassung in der ältesten böhmischen Hagiographie. Es ist erkennbar, dass dem kleinsten, teils zufälligen Segment der historisch mit den ersten Angehörigen des Přemyslidengeschlechtes verbundenen Burgwälle eine ungefähr zehnfache Aufmerksamkeit als den übrigen böhmischen Burgwällen zuteil wird. Nach der Archäologischen Karte der Tschechischen Republik, Stand 2016.

geografických horizontů ve čtyřech logických úsecích kroniky (1 - období mytické; 2 - období legendární / první polovina 10. století; 3 - období z Kosmova pohledu historické / druhá polovina 10. a první polovina 11. století; 4 - období z Kosmova pohledu autooptické / po 11. století až 1125; viz Hasil v tisku), zjistíme, že na rozhraní posledních dvou horizontů se jasně odráží dvoj- či vícerychlostní integrace dílčích oblastí do struktury přemyslovského státu (viz obr. 4). Současné archeologické poznatky o vývoji centrality v Čechách 10. století (Profantová-Tomková 2018) s těmito výsledky plně korelují, je však otázkou, zda jsme zde na stopě historické skutečnosti, či výrazného ovlivnění archeologické evidence historickým vyprávěním. V té partii textu, která se vztahuje ke kronikářově současnosti, se zřetelně odráží struktura tehdejších nejdůležitějších zemských komunikací (obr. 5). 


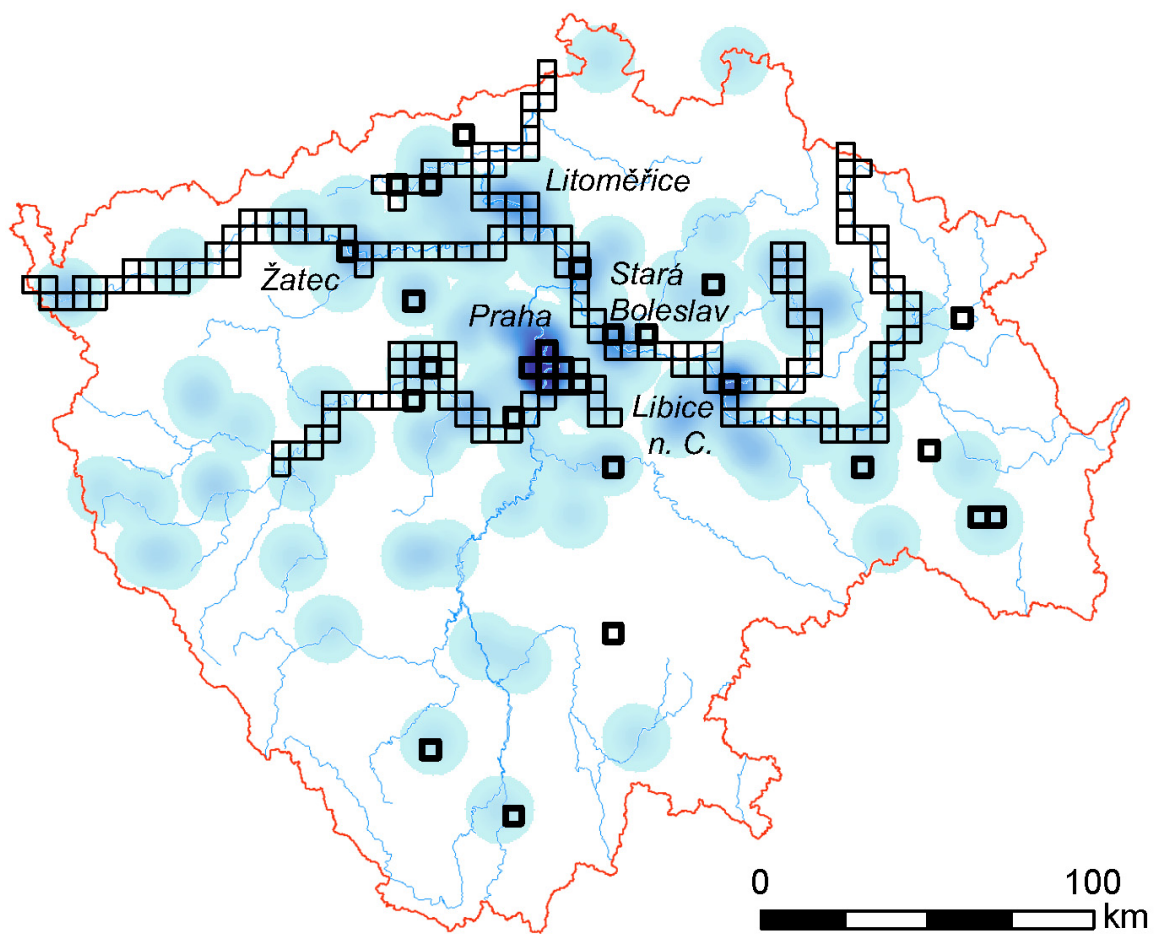

Obr. 4. Čechy druhé poloviny 10. a počátku 11. století vykazují značnou regionalizaci. Teplotní mapa shrnuje archeologické doklady centrality (podle Profantová-Tomková 2018, Fig. 1-4), rastr pak místa zmíněná v chronologicky příslušných pasážích Kosmovy kroniky. Na základě obou evidencí lze hovořit o heterogenitě tehdejší společnosti Čech a regionálním rozrůznění intenzity vazeb jednotlivých regionů na rodící se přemyslovský stát.

Abb. 4. Das Böhmen der zweiten Hälfte des 10. und des Anfangs des 11. Jahrhunderts weist eine beträchtliche Regionalisierung auf. Die Temperaturkarte fasst die archäologischen Belege für Zentralität zusammen (nach Profantová-Tomková 2018, Fig. 1-4), das Raster dann die in den chronologisch entsprechenden Passagen der Cosmas-Chronik erwähnten Orte. Auf Grundlage beider Angaben kann man von einer Heterogenität der damaligen Gesellschaft Böhmens und einer regionalen Diversifikation der Intensität der Beziehungen der einzelnen Regionen zum entstehenden Přemyslidenstaat sprechen.

\section{Ozvěny „středoevropského modelu“}

Jedním z důležitých témat, která nenacházejí vysvětlení v kosmovském líčení českých dějin, je (dis) kontinuita nižších společenských elit, respektive diskuse o zformování pozemkové šlechty. ${ }^{12}$ Př́i studiu vrchnostenských sídel se různí autoři (Kolektiv 1998-2005, V-VII; Durdík 2000; DurdíkBolina 2001) jako o pevné východisko - i když často zamlčené - opírají o výklady F. Grause (1965), D. Třeštíka (1971) a J. Žemličky (2003; 2009). To vede k celému cyklu závěrů centralizovaných kolem fenoménu hradišt' a moci panovníka i k praktickému popření př́imé vazby šlechty na raně středověkou pozemkovou elitu. Konfrontovat je nutné zejména vybraná tvrzení o tzv. středoevropském

12 Jako pracovní hypotézu lze zformulovat tezi, že se jedná o jeden z „Kosmových záměrných omylư“ (srov. Sláma 2003), tj. o jednu z mezer Kosmova diskursu (mezi další patří například sjednocování Čech pod vládou Boleslavů, úloha klášterů či fenomén slovanské liturgie). V případě literárního díla, které vyšlo z konceptu gest českých knížat a pražských biskupů (viz Hasil-van Rensvoude 2019), je podobná mezera v líčení v zásadě dobře pochopitelná a odpovídá jiným náznakům společenského strukturování přemyslovského státu, které dílo pražského děkana zmiňuje zcela okrajově (srov. Žemlička 1998). 


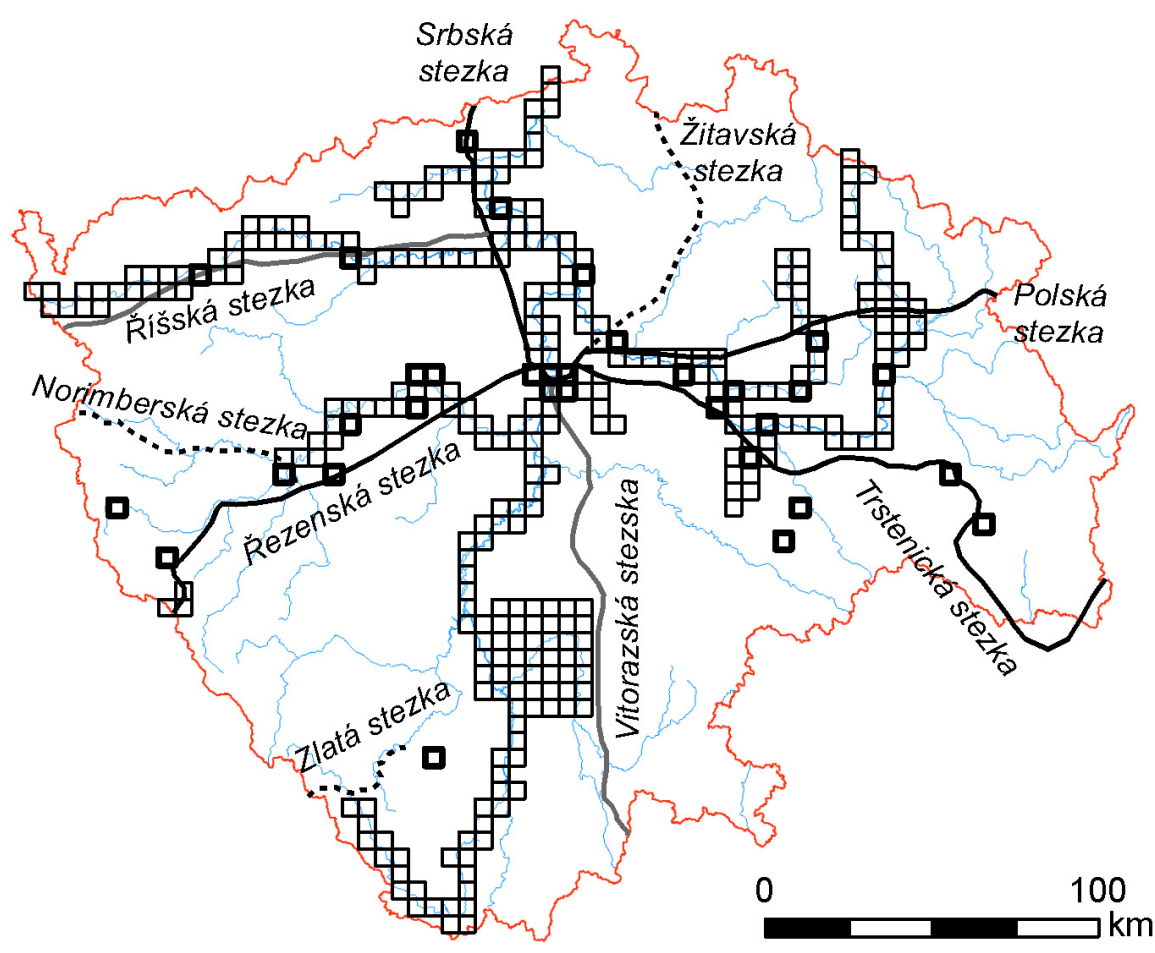

Obr. 5. Čechy druhé poloviny 11. a počátku 12. století. Strukturní analýza textu stř̌edověkého narativního pramene poměrně věrně odráží stav dálkových komunikací v Čechách v době kronikářova života (̌̌ezenská, Vitorazská, Trstenická, Polská, Srbská a Říšská stezka), zatímco mladší významné komunikace (Norimberská, Zlatá a Žitavská stezka) nejsou geografickým záběrem textu postihnuty.

Abb. 5. Böhmen in der zweiten Hälfte des 11. und am Anfang des 12. Jahrhunderts. Die Strukturanalyse des Textes der mittelalterlichen narrativen Quelle spiegelt die zur Lebenszeit des Chronisten in Böhmen existierenden Fernstraßen relativ getreu wider (Regensburger Weg, Weitraer Weg, Trstenitzer Landessteig, Glatzer Handelsweg, Kulmer Steig und Reichsstraße), während wichtige jüngere Verkehrsstraßen (Nürnberger, sog. Goldene /nach Passau/ und Zittauer Straße) vom geographischen Rahmen des Textes nicht erfasst werden.

modelu a služebné organizaci (souhrnně Třeštík-Žemlička 2007; Žemlička 2012), která se bohužel chybně přenáší i do zahraničních publikací (např. Curta 2009). Model vychází z hypotézy, že panovník spolu se svou družinou postupně téměř vymýtili starší rodovou vrchnost a položili základ nové beneficiární (později feudální) elity na troskách služebné organizace a hradské soustavy. Celý konstrukt vychází z představy o knížecím regálu „na půdu a lidi“. Taková pozorování stojí v kontrastu s druhým názorovým proudem, zakládajícím se na pracích počínajících $\mathrm{F}$. Palackým (vývoj názorů shrnují Zelenka 2016, 107-120; Kalhous 2011-2013, II, 244-248; Petráček 2012, 21-52; Vaníček 2003; 2015), stejně jako na nových impulzech L. Jana (2000; 2007; 2007a; 2007b; 2015), V. Vaníčka (1994; 2003; 2011), T. Petráčka (2012) a dalších autorů. Tato skupina badatelů hovoří spíše o nepřímém vlivu panovníka na řízení raně středověkého státu, a to cíleným usměrňováním jednotlivých rodových domén. Nevylučuje sice nakládání s úřady jako beneficii, ale ty vidí hlavně jako prostředek k zásahu do vnitřní rodové politiky a pozdvižení sociálního statusu konkrétních osob. Představa o náhlé emancipaci šlechty vedla k interpretaci, že vznik sídel byl prostým importem západoevropského modelu feudality. Naproti tomu druhá výkladová verze značí 
spišse pozvolnější proměnu vycházející z domácích kořenů, kdy významnou roli ve společenské organizaci hraje knížecí velkostatek navázaný jen částečně na hradskou správu.

Tzv. středoevropský model nevysvětluje, z jakého substrátu se zrodily venkovské dvorce již v průběhu raného středověku a jak je zdůvodnitelná jejich kontinuita do 14. a 15. století. Model opomíjí kritické zhodnocení lokální dostupnosti zdrojů nutných pro jednotlivé poskytované služby a dostatečně neřeší ani vznik sídel nobility. I s historicky prokázanými rodovými klany se vyporrádává prostou násilnou asimilací. Problémem je i otázka věrohodnosti toponomastických určení, na kterých stojí celá jedna větev interpretace (viz Klápště 2005, 307-315). ${ }^{13}$ Takovou vlnu změn, jakou by přinesl přerod od služebné organizace k feudálnímu státu, lze stěží vměstnat do intervalu konce 12. století a počátku 13. století. Pokud by skutečně bylo užívání otrocké pracovní síly beneficárními úředníky běžné (viz Třeštík-Žemlička 2007, 122), těžko lze předpokládat přechod k emfyteuzi, aniž by se dřívější uspořádání projevilo $\mathrm{v}$ alespoň marginálních pokusech zachovat tuto tradici, eventuálně její části adaptovat. Vysvětlení př́ípadné diskontinuity společenského uspořádání chybí, protože základem vrcholně středověké společnosti byly domácí rody (včetně nezměněné vládnoucí dynastie), nikoli nezávislá komunita nově příchozích (Jan 2000, 189).

Pokud měla služebná organizace vycházet $\mathrm{z}$ velkomoravské tradice (a díky tomu se šírit nejen v Čechách, ale i v Polsku a Uhrách) ${ }^{14}$ není zřejmé, proč prominentní místa ve dvorcích na akropoli Pohanska neobsazují vojenští družiníci, ale řemeslníci a kupci. První jmenovaní, tedy milites, sídlili podle archeologických nálezů na předhradí a spojujeme s nimi chudší vybavení (Macháček 2005, 110-131), což naznačuje i jejich nižší společenské postavení. Ani honosné románské kvádříkové domy pražského podhradí nejsou interpretovány jako pozůstatky sídel milites či beneficiářů ale jako obydlí kupců (Dragoun et al. 2002). V praktickém sociálním životě tržně-ekonomická moc zjevně dlouhodobě vítězila nad životem vojáků a formálním postavením ministeriales, kteří skutečně mohli být vybavováni ze společných zásob, jak uvádí Třeštík a Žemlička (2007, 137-139); nikoli však jako rodící se elita, ale jako správní aparát. Neměla by samozřejmě být zpochybňována nutnost hospodářského zajištění hradišt', ani význam účasti užší panovnické družiny (milites primi ordini) na válečných aktivitách a v důležitých úřednických postech. Mezi nimi můžeme hledat původ nejlépe situovaných velmožů (Jan 2009, 472; Petráček 2012, 117-122), kteří zároveň byli i rodovými předáky a „staršimi země“, vázanými př́ísahou věrnosti (Wihoda 2007, 18). Chybí ale vysvětlení, k čemu by movitějším beneficiářům z dvorského okruhu byly dokládané bohaté výsluhy (Třeštík-Žemlička 2007, 142), když by zároveň nemohli disponovat půdou, kde by své výdělky investovali. Nelze předpokládat, že by je užívali pouze pro zapojení do dálkového obchodu s luxusním zbožím - takový systém, pokud vůbec mohl v této své podobě fungovat, se ve stř̌ední Evropě překonal již s úpadkem Velké Moravy (Štefan 2011). Pak ale musíme anticipovat fungování (omezeně dostupného) lokálního trhu, stavební iniciativy a nájemné pracovní síly, snad v souvislosti s budováním na panovníkovi nezávislých domén. Ty mohly být i velice malé a rozptýlené, např́klad v rozsahu jednotlivých vesnic, jak naznačuje pozdější situace známá z vrcholného a pozdního stř̌edověku (Petráň 1976, 15-16, 31-32; Novák 2019a, 368), a o to závislejší na existenci uvedených tržních vztahů.

Vladycké rody nemusely pocházet z militárního a úřednického prostředí. Vždyt' i vojensky vázaní manové pozdního středověku, stejně jako rychtáři a nápravníci, stáli na nižším sociálním stupni než drobná rodová šlechta (srov. Sedláček 1882-1927, VIII, 147-150; Macek 1997, 50-65). Stejně tomu bylo i s milites ve službách Hroznaty Tepelského, kteří zcela záviseli na vůli svého seniora (Klápště 2005, 76). ${ }^{15}$ Služebná organizace v českých zemích v puristicky obhajované podobě nemohla existovat a strukturování elit spočívalo dokonce snad i v jiném sociálním podhoubí

13 Užívání „profesních“ názvů pro sídelní jednotky není nijak výjimečný jev ani za našimi hranicemi a souvisí s obecnější problematikou tvoření toponym (Meduna 2009, 204-207).

14 Což samo o sobě lze zpochybnit (viz Štefan 2011, 348-349).

15 Předlohou tohoto uspořádání, již se snad přidržel Hroznata Tepelský, a kterou může využít jako výkladový model i současné bádání, byla patrně ministeriální struktura na Chebsku, které s Hroznatou a jeho državami bezprostředně souvisí jak dějinně, tak geograficky (Hasil 2018, 228-229). Zpracování tématu chebské ministeriality z pera F. Kubů (souhrnně 1997) pokládáme - díky tematickému a paradigmatickému transferu z německého prostředí - za jednu z nejinspirativnějších studií ke středověkým elitám v českém prostředí. 
(řemeslnicko-kupeckém $\rightarrow$ budoucí měšt’ané; klanovém $\rightarrow$ budoucí šlechta). Převládající interpretace o centralizovaném pozemkovém vlastnictví a roli panovníka na velkomoravském prríkladě se ostatně pokusil rozporovat již P. Charvát (1987), když upozornil na alternativní modely decentralizované držby, potenciálně kompatibilní s výpovědí archeologických pramenů. Vše nasvědčuje tomu, že společenská organizace již od raného stř̌edověku stála na postupné kumulaci rodového pozemkového i movitého majetku a upevňování individuální moci předních představitelů rodů, a je tak mnohem podobnější vrcholně středověkému prostředí, než jak jsme zvyklí si připouštět na základě disparátně běžících diskursů o dílčích obdobích středověku.

\section{Aktualizovaná východiska studia elit středověkých Čech}

Uvedené archeologické i historické doklady již v současnosti dovolují a vyžadují celkovou reformulaci modelu vývoje Čech v raném středověku a zahlazení existujících slepých míst. Celý proces středověké proměny je třeba chápat jako právně-sociální transformaci komunitních a rodových společností, založených na osobních vztazích, ve středověký stát s jeho institucemi a úředním aparátem, a to pod vedením vládnoucího rodu a v intencích jím nastavených (Petráček 2012 , 118). V důsledku dochází $\mathrm{k}$ růstu komplexity sociokulturního uspořádání a ke vzniku nových sídelních forem (Vaníček 2003; 2011). Širokou a mnohovrstevnatou skupinu rodící se nižší šlechty nejpozději pro 12. století dokládají početné donace drobných, někdy bezejmenných pozemkových vlastníků ve prospěch církevních institucí, hlavně klášterů (Nováček et al. 2010, 135-139; Jurok 2000, 13-14; Jan 2009, 463; obecněji Gurevič 2008, 15-16), které tvořily místa kontaktu s panovnickou a církevní mocí a fakticky i duchovně na sebe vázaly lokální elity (Kalhous 2018, 50). Přesto již při zakládání kladrubského kláštera kolem roku 1115 nemohl panovník volně disponovat řadou statků v jeho okolí, protože mu fakticky nepatřily (Nováček et al. 2010, 128-129). Přidat lze i oporu v podobě starších přímých zmínek o původních rodech v Kosmově kronice a u jeho pokračovatelů (Wihoda 2007) a nakonec i ve fenoménu darovaných lidí, tedy snad prapůvodní nesvobodné čeledi postupně se měnící v poddanstvo (Petráček 2012). Porozumění roli jednotlivých rodin a klanů (širších rodů) tvořících občinu a jejich právní reflexe v definici nedílu (tj. vyjasnění principů dědictví) mohou být vhodná východiska pro pochopení uspořádání předfeudální elity a vztahů k půdě. Spory popsané v této souvislosti naznačují, že geneze svobodné držby byla sice postupná, nicméně z podstatné části vycházela z původní klanové držby nezávislé na panovníkovi a jeho vůli (Laval 2016, 70-78).

Model feudální společnosti, jehož odrazy se objevují v pramenné evidenci k českému území od přelomu raného a vrcholného středověku, má přirozeně svůj předobraz v západněji položených teritoriích. Ani tam však nebylo uspořádání společnosti přirozeně stabilní a neustále se vyvíjelo, nadto $\mathrm{v}$ různých regionech odlišně. Východiska pozdně antického a merovejského období podchycují jako první tzv. barbarské zákoníky, které kodifikují lokální zvyková práva, doplňují je o prvky ř́mského práva a přizpůsobují je potřebám církve i požadavkům domácích vládnoucích elit (Hechberger 2005, 155-183; Macháček 2008, 610-611). Rané feudální vztahy byly založené vesměs soukromoprávním aktem (komendací do rukou budoucího pána, družinickou přísahou či vazalským slibem - Patzold 2012, 14-25) a svou podstatou vycházely z reciprocity závazku, symbolicky vyjádřeného dary či hostinami (Gurevič 2008). O těchto ceremoniálech sice normativní texty vypovídají omezeně, odrážejí se však v narativních pramenech. Jejich stopy nalezneme ještě v nejstarší václavsko-ludmilské hagiografii. Značně ritualizované podoby nabývaly i z dnešního pohledu velice živelné události, jakými byly např́klad ozbrojené konflikty. Veřejné rituály nastavovaly celková ,pravidla hry“ (něm. Spielregeln) a definovaly sdílený symbolický jazyk středověké elity, téměř na úrovni normativu (Althof 2020). Je proto třeba předpokládat velice variabilní inspirační východiska feudalizace společnosti přemyslovského státu i jejích vnějškových a materiálních projevů. Určující úlohu měla komunita, ve které subjektivní společenské role nebyly natolik významné, aby jednotlivce stavěly do fundamentálně odlišného právního postavení. Rozhodně můžeme vyloučit představy o vyhraněné společenské hierarchii, jež bychom 
získali prostou zpětnou extrapolací mladších právních zrcadel (zejména Sachsenspiegelu; srov. Zelenka 2016). Vodítko k pochopení procesu definování středověkých elit leží i v užívané titulatuře; pojem vladyka označuje držitele půdy odlišné od vrchnosti v lenním vztahu vůči seniorovi, jejíž príslušníci vystupují v pramenech jako nobiles, milites či clientes (Vykypěl 2004, 101-113; Macek 1997, 68-90). Skeptické poznámky k neschopnosti historiografie odpovídat na podstatné otázky období 10.-13. století (Klápště 2012) jsou proto spíše přehnané, protože problém neleží toliko na úrovni pramenné báze.

Obraz nástupu vrcholně středověké vrchnosti a jejích sídel asi nejlépe zapadá do syntézy názorů L. Jana (2007b; 2009; 2015) a umírněnějších prací J. Klápště (2005, 17-166), F. Lavala (2013, 49-59; 2016, 70-82), J. Zelenky (2016, 168-173) a T. Petráčka (2012, 159-162). Problém dosavadních pojetí spočívá v přeceňování provázanosti centrální moci a lokálního společenského a majetkového postavení na úrovni regionů a komunit. $\mathrm{V}$ podstatě se pak nerozlišuje mezi vládnutím centrální moci a neomezeným vlastnictvím země a lidí (srov. Žemlička 2009), což patrně vyplývá i ze staršího marxistického diskursu (Wihoda 2007, 9-16). Je třeba přiznat, že v historické perspektivě je vlastnictví velice neurčitý pojem podléhající neustálé negociaci, naplňovaný subjektivním vztahem vůči různým typům vrchnosti (církevní i světské) a projevující se v různých úrovních. Objevují se názory, že struktura a stabilizace forem vlastnictví ve středověku byla pouze důsledkem výkonu moci a její institucionalizace, nikoli jejím východiskem (West 2013). Takový pohled by však jen zpětně potvrzoval, že sledujeme-li nejpozději od sklonku 11. století v Čechách stabilizující se majetkové poměry, muselo tomuto procesu předcházet odpovídající nastavení sociálních vazeb i jejich ustálení a případná pozdější diskontinuita elitního prostředí by opět postrádala vysvětlení.

Rozvinutý přemyslovský stát byl sice velmi pravděpodobně založen na vytváření úřrednické elity, přičemž nejúspěšnější osoby mohly požívat značných výsad a své postavení si udržet i po ustavení zemských úřadů, které odpovídaly stále rostoucím nárokům na organizaci a stabilizaci státní moci. Šlechta se však na formování i výkonu společenských a právních norem podílela dlouhodobě a hluboko před 13. stoletím (Jan 2000; Nodl 2007; Novotný 2007). Paralelně k tomu existovalo v raném středověku menší pozemkové vlastnictví, které dávalo základ pro růst lokálních majetkových odlišností a zrod elity nižších stupňů. S tím počítáme nejpozději od 11. století, kdy v Čechách definitivně mizí systém charakteristický spíše pro pravěké komunitní sociální uspořádání (Macháček 2008, 612). Vývoj raně středověké společnosti k tomuto bodu však patrně směřoval podstatně déle, nejpozději od 8 . století, jak dokládají výše zmiňovaná dobře vybavená elitní sídla rozptýlená na okrajích sídelní zóny (Profantová 2000). Mezi těmito východisky hledejme základ i pro početnou nižší šlechtu, která byla nevelkým majetkem a roztříštěnými pozemky definovanou elitou z řad méně významných př́islušníků původních klanů. Byla charakterizována familiemi, kterým se nedostalo panovníkovy přízně, a tedy ani významnějšího úřadu (vladykové; Laval 2013, 56; Macek 1997, 68-90).

Specifikem českého státu nebyly centralizovaná vláda jednoho rodu a modelově snadno uchopitelná služebná organizace. Bylo to kombinované působení rodové samosprávy založené na kontinuitě vlastnictví (Klápště 2005, 76-77; Jan 2009, 470), přítomnost vrstvy svobodných spojené s odváděním dávek pro nespojité panovnické velkostatky obhospodařované ze dvorců (Meduna 2009, 207-208; Petráček 2012, 97-114) a vliv hradské organizace (Sláma 1987), která měla úlohu správní, nikoli však mocensky monopolní. Svou tradicí taková východiska odkládala a omezovala vliv lenního zřízení pronikajícího postupně ze západní Evropy (Zelenka 2016, 21-103) a zformovala základ společenských struktur, které utvářely naši krajinu po další staletí. ${ }^{16}$ Souběžně s vývojem feudálního zrrízení se z řemeslnicko-kupeckých hradištních center (jejich předhradí i podhradí) přirozeně formovaly protoměstské aglomerace (Klápště 2005, 363-388). Nejpřijatelnější je patrně pojmosloví V. Vaníčka, který hovoří o postupné „modernizaci“

16 Zelenka ve své práci zároveň prokazuje, nakolik významově podobné jsou ve výsledku pojmy beneficium $\mid$ feudum $\mid$ lehen (Zelenka 2016, 63-68; na jiných př́íkladech Jan 2009, 469). 
středověké společnosti (Vaníček 2003; 2007; 2011), vrcholící v pozdním stř̌edověku a doznívající $\mathrm{v}$ různých formách až do třicetileté války.

$\mathrm{Z}$ prezentované diskuse vystupuje do popředí zejména přímočaré a $\mathrm{v}$ důsledku chybné propojování archeologických zjištění s historickými naracemi, a to bez patřičné odezvy archeologické obce. Archeologie jen využila př́iležitosti převzít koncept vystavěný pod hlavičkou tzv. středoevropského modelu. Opět to byla historiografie samotná, která model korigovala. Současná archeologie středověku tuto změnu v diskursu dosud řádně nereflektovala a vzhledem k vlastní teoretické nevyhraněnosti (a tím pádem i slabému vztahu k pramenům) historiografickému výkladu může pouze sekundovat. Pokud vidíme nekritické odkazování ke služebné organizaci jako $\mathrm{k}$ dogmatu pojímanému téměř na úrovni pramene, je o to zřetelnější uměle vytvořená diskontinuita mezi raným a vrcholným středověkem, která se pak silně podepisuje na celé sféře témat. Ta do svého rámce zahrnuje např́íklad kastelologie, proto ji uchopme jako vhodný př́iklad pro popis nesnází, se kterými se současné prŕstupy k historické archeologii potýkají.

\section{Kastelologie - nepřenositelný koncept svébytnosti}

Snad právě jako reakce na univerzalismus české historické vědy, který potlačoval dílčí a regionální témata, se od 70 . let 20. století formovala pestrá skupina badatelských osobností z akademické, aplikované i amatérské sféry pod praporem české školy kastelologie. V počátečních fázích bádání bylo studium (opevněných) sídel vnímáno jako spojitý problém s kořeny v pravěké a raně středověké situaci. Hrady byly pokládány za konstituent sídelní struktury navazující na starší hradiště, ale také za hlavní výraz vrcholně středověké proměny ve smyslu nového prvku sídelní struktury. S postupem času došlo bohužel i zde k roztříštění bádání na dílčí subkategorie definované nikoli tematicky, na základě teoretických otázek, ale formalisticky, podle přejímaného historického pojmosloví (hrady, tvrze, zámky...). Tyto skupiny se následně staly silnou linií diskontinuity a záběr jednotlivých badatelů se velmi specializoval, prrípadně se realizoval na úrovni výzkumu konkrétních objektů. Proto v tuzemsku stěží stopujeme průřezová témata, která by tyto rámce překračovala a snažila se své závěry zobecňovat. Byly to silné osobnosti poválečného období (D. Menclová) a poslední čtvrtiny 20. století (T. Durdík), které českou diskusi svou autoritou ovládly a nastavovaly přípustná témata i metody. Nejvíce inspirativním způsobem tak často nahlíželi (a nahlížejí) na oblast kastelologie ti autoři, kteří se jí věnovali jako jednomu z dílčích zájmů (namátkou A. Hejna, Z. Měřínský, J. Klápště, P. Chotěbor, P. Kouřil, M. Ryk1, R. Šimůnek).

Problém z velké části leží v mezioborovosti kastelologie, která není podpořena patřičným teoretickým rámcem a badatelským zázemím (Razím 2004, 209; Novák 2019). Pro srovnání u archeologie venkovských sídlišt' zůstáváme zařazení do oborového diskursu a archeologické studium středověkého rurálního prostředí (především díky poslání celoevropské společnosti Ruralia) se profiluje zcela opačně než česká škola kastelologie. Je to široká otevřená platforma orientovaná na komparativní výzkum, která však bazíruje na své archeologické podstatě. Zformování této odborné společnosti bylo ostatně možné i zásluhou organizační činnosti pracovníků pražského Archeologického ústavu, zejména Z. Smetánky a J. Klápště. V čem se přitom v praxi tato témata liší? V př́ípadě kastelologie vznikla potřeba definovat se nad úrovní oborů. Co k tomu vedlo, je těžko soudit, snad to byla samotná atraktivita a zdánlivě snadná uchopitelnost tématu. Dosavadním výsledkem na poli studia elitních sídel je ale hlavně alarmující rozkol mezi teoriemi a metodami prehistorické, protohistorické a historické archeologie.

Mnohé vystihuje poznámka D. Kováře (2011, 7): „Legitimní snahou kastelologie jako každé seriózni vědni discipliny je vytvořit určité kategorie, schéma vývoje a jednotlivá sídla ,zaškatulkovat‘. Jenže prirozený vývoj neprobihal a neprobihá ve škatulkách, a tak se s pokračujicím bádáním objevuje v teoretické rovině kastelologie stále více nejasností a otázek." Budeme-li potom českou školu kastelologie nahlížet širší chronologickou perspektivou, což je z hlediska zaměření tohoto příspěvku klíčové, zjistíme, že vyprodukovala jen malé množství znalostí, jež 
by bylo smysluplné extrapolovat do starších či naopak mladších období dějin. ${ }^{17}$ Pro období raně středověké zde chybí materiálové jádro, na němž kastelologický diskurs stojí (viz teze o hradech prechodného typu), $\mathrm{v}$ mladších obdobích lépe pokrytých alternativní pramennou evidencí se potom rychle vyprázdní podstata tradičních kastelologických otázek (osoba stavebníka a majetkové souvislosti, chronologické zařazení atp.). Vybereme-li ilustrativní tvrzení - jak nepřesvědčivě kupř́ikladu zní, že z obranného hlediska v podstatě nefunkční aplikace francouzského kastelu v Čechách je výrazem ,nepochopeni“ původního záměru - aktivní obrany (Durdík 2000, 27; 2009, 134). Těžko se domnívat, že by středověcí stavebníci (v př́ípadě tzv. kastelů dokonce z královského prostřredí) nezvládli pochopit původní účel věží a věžic vysunutých vně opevnění. Mnohem pravděpodobnější je, že $\mathrm{v}$ kontextu dobové mentality šlo $\mathrm{v}$ tomto konkrétním užití o naprosto podružné hledisko. Nepochopení záměru tak leží více na straně současného badatele, nevědomky se omezujícího vlastním paradigmatem.

Podíváme-li se přitom na témata přesahující v Čechách typický výkladový rámec vývoje sídel, důležité nové impulzy přináší například dendrochronologie užitá při revizi zahraničních výzkumů, která zlatý věk budování sídel typu motte posouvá do českému prostředí mnohem bližšího 12. a 13. století s dozníváním až ve 14. století, a to jak ve Skotsku, Irsku a Dánsku, tak překvapivě i ve Francii, Anglii a Německu (Creighton 2012, 93, 101-102). Domnělý posun mezi počátkem budování „typických“ elitních sídel v Čechách a ve zbytku Evropy proto nemusí být tolik zřetelný, jak se dosud předpokládalo. V takové chvíli totiž celá konstrukce zapadá do běžného průběhu difuze inovací, jak jej popisuje sociologická teorie (obr. 6). Byt' časová složka difuze mohla být ve středověké společnosti odlišná od té moderní, protože podstatnou roli hraje efektivita šíření znalostí a kulturní bariéry, její princip zůstává zachován (Rogers 1983, 202-209). ${ }^{18}$ Dosavadní interpretace relativně rychlého nástupu nového charakteru kamenných sídel stanovovala, že měl být nesen pouze nejvyššími elitami (panovníkem a jeho okolím; např. Durdík-Bolina 2001). To však neodpovídá ani realitě (původ většiny sídel je s panovníkem spojován spíše účelově a nejde o jediný typ kamenných elitních staveb), ani zmíněné teorii, která předpokládá nutnou vyšší míru akceptace podstatnou částí společnosti pro tak široké a relativně rychlé uplatnění inovace. S postupujícím výzkumem tak sílí otázka, zda dosud přijímaný hiát mezi západní a východní Evropou vůbec existuje, když naopak české lokality postupně začínají nacházet své počátky ve 12 . století. ${ }^{19}$

České studium sídel elit se přesto chová nepřirozeně uzavřeně. Ilustrativním příkladem je jeden z nejdiskutovanějších českých hradů na česko-bavorském pomezí - Přimda. Ta dodnes postrádá komparativní analýzu v kontextu hornofalcké skupiny románských hradů (mj. Flossenbürg, Leuchtenberg, Parkstein - viz např. Boos 1993), s nimiž je v bezprostřredním geografickém i chronologickém „,dotyku“. I přes dlouhou dobu, po kterou český panovník vlastnil tento moderně působící hrad s mohutnou kamennou věží (Durdík 2009a), nevešla stavba typově obdobných kamenných sídel v Čechách do módy dříve než počátkem 13. století. ${ }^{20}$ Jedná se o zcela vědomé a aktivní (i když jen dočasné) odmítání inovace. Při jejím přijímání je však determinující velké množství proměnných. Roli hrál např́íklad procentuální podíl osob, které měly možnost se s inovací stř̌etnout (za rozhodující hranici pro přijetí bývá považováno ca 20-30 \% populace; Rogers 1983, 240). Uvažování české aristokracie - panovníka a jeho nejbližší okolí nevyjímaje - proto muselo dospět k docenění nové stavební formy až po přijetí západoevropských kulturních vzorců

17 Kastelologické východisko je zřejmé v př́ipadě studia starých komunikací (Bolina-Klimek-Cílek 2018; Bolina-Cendelín 2014), které se však od studia hradů paradoxně výrazně odlišuje zásadním akcentem na vstupní teoretické či alespoň induktivní předpoklady

18 „V procesu lze konceptualizovat pět kroků: (1) znalost, (2) přesvědčení, (3) rozhodnutí, (4) implementaci a (5) potvrzení. Pro snižení míry nejistoty o inovaci jedinec hledá informace v rủzných fázich inovačního a rozhodovacího procesu. (...) Rozhodovaci fáze vede (1) $k$ adaptaci, rozhodnuti plně využit inovaci nejlepšim možným zpưsobem, nebo (2) k odmitnutí, rozhodnutí inovaci neprijimout. (...) Rozlišujeme pět kategorii př́jemců, tedy tř́d členů sociálního systému na základě jejich inovativnosti: (1) inovátory, (2) brzké přijemce, (3) progresivní většinu, (4) požděnou vétšinu a (5) zpátečníky." (Rogers 1983, 36, překlad DN).

19 Jedná se o menší sídla typu Čimic (Laval 2013, 35-37) či Kralovic (Procházka 2008), včetně těch doložených prvními predikáty (srov. Klápště 2005, 88-99) a spojovaných s emporovými kostely (srov. Laval 2013;2016). Sídla patrně mnohdy zůstávala v majetku jednoho rodu po celé klíčové období od 12. do 14. století - například ze Svojšina (Sedláček 1882-1927, XIII, 136); z Vintířova (Kolektiv 1997-2005, 952-953); ze Železnice (Durdík 2009, 643) aj.

20 Přestože předzvěst jejich stavby mohou představovat kamenné sakrální stavby spojované se dvorci (viz Laval 2016), v tomto případě mluvíme o kvalitativně jiném typu stavby, který má veškeré znaky vrcholně středověkého hradu. 


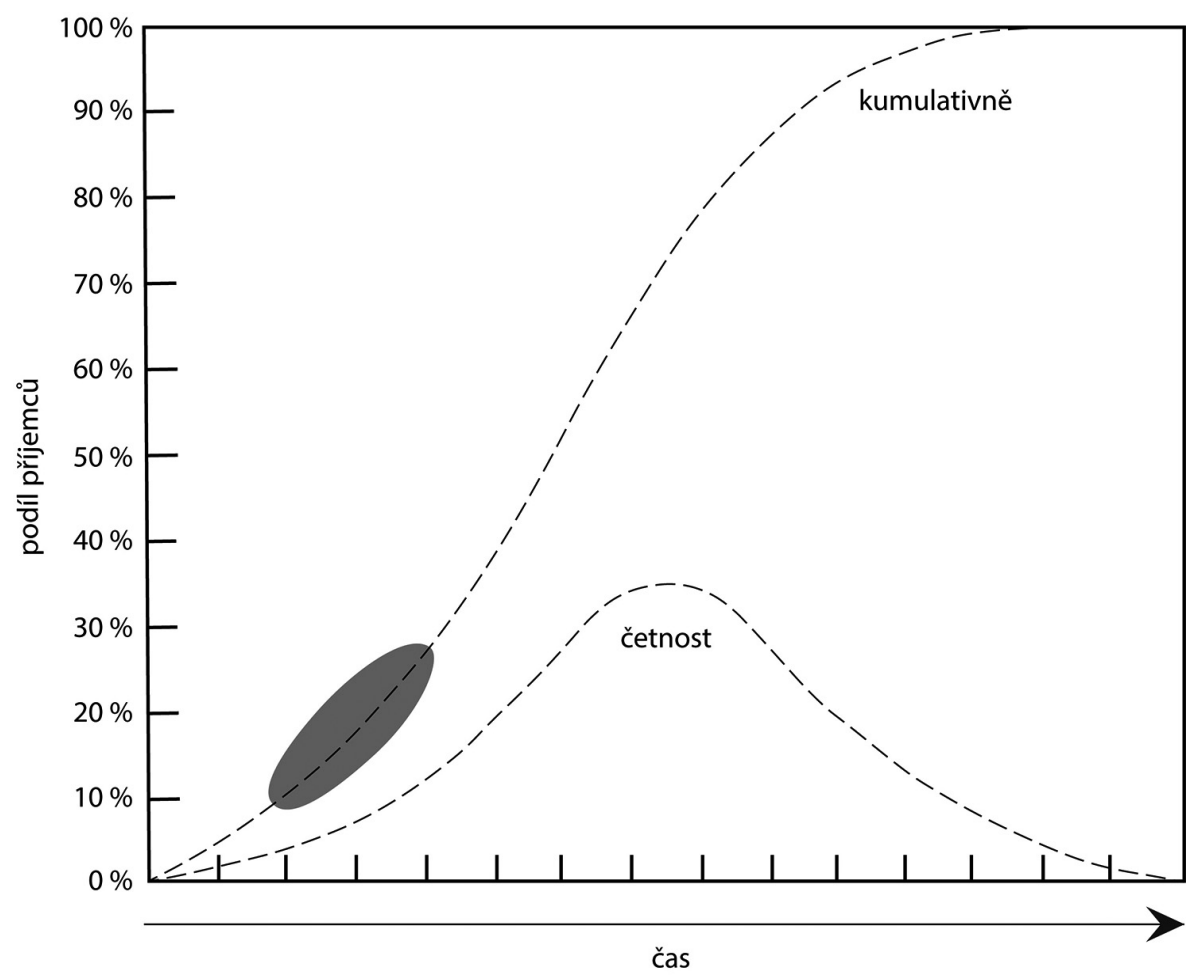

Obr. 6. Grafické vyjádř̌ení průběhu příímání inovací v čase. Zvýrazněna oblast kritická pro akceptaci inovace celou společností. Upravil D. Novák podle Rogers 1983, 243.

Abb. 6. Grafische Darstellung des Verlaufs der Annahme von Innovationen im Lauf der Zeit. Hervorgehoben ist der für die Akzeptanz einer Innovation von der gesamten Gesellschaft kritische Bereich. Bearbeitet von D. Novák nach Rogers 1983, 243.

a vzniku dostatečného počtu osobních vazeb mezi českou a západoevropskou elitou, resp. formami elitní reprezentace. Vysvětlení tak v principu leží mimo přirozený záběr kastelologů a jedině pohled mimo něj umožňuje celý problém korektně tematizovat. Pregnantně jsou možné přenosy forem sídel doloženy $\mathrm{v}$ raném novověku, v souvislosti s kavalírskými cestami mladých šlechticů (Kubeš 2008, 80), kteří znalosti aktivně přenášeli. Starší obdobu lze spatřovat v šíření idey rytířství a typické šlechtické reprezentace, včetně ritualizovaného konfliktu a literárních projevů (Vaníček 2007). Zvláště v př́ípadě méně majetných vlastníků a jejich drobných sídel měly ale „znalostní sítě“ středověku velmi omezený dosah (Rykl 2008, 35), na rozdíl od možností panovníka a movitějších rodů.

Diskuse o roli konkrétních osob při tomto procesu není u nás nikterak nová, avšak z archeologického hlediska vedla k neproduktivnímu studiu přenosu konkrétních stavebních řešení (Menclová 1976; Durdík 2000), včetně úvah nad přirozeným zdomácněním dispozičních řešení zahraničního původu v opozici k ryze domácím typům (Durdík 2000; Durdík-Bolina 2001, 137). Zde je př́íhodná poznámka O. Creightona (2012, 40, překlad DN): „,...) architektura se nešiří sama o sobě, vzájemným ovlivňováním stavebních forem. (...) Pro způsob výběru architektonických prvků a jejich adaptace je podstatná role individuálních agentů, zejména dynamický vztah mezi stavebniky a iniciátory staveb provázanými ve znalostni síti. "Logickými uzlovými body znalostních sítí a místy pronikání nových prvků tak byla multikulturní městská centra. Takovým byla například předlokační Praha právě tam nacházíme řadu nejstarších kamenných staveb různých typů. 
Klíčová se zdá být i souvislost kamenných sídel a církevních staveb, která není pouze prostorová, ale do značné míry i genetická. Založení sakrální stavby nebo navazování blízkých vztahů rané šlechty a církevních institucí pomocí donací je třeba chápat jako konstruování základů rodové identity (Šimůnek 2013, 67-135). Kostelní věž předrománského a románského období pak lze chápat také jako profánní stavbu, první zděnou architekturou svého druhu u nás, která př́mo předchází hradům a tvrzím (odtud snad etymologický vývoj castellum $\rightarrow$ kostel) a plní zcela svébytné funkce. Stavba věže někdy přímo či nepřímo přiléhá ke kostelní lodi, prostorově a komunikačně oddělené kapli, tedy vlastní sakrální stavbě (Laval 2013; 2016). Souvislost emporových kostelů a nejstarších sídel byla delší dobu zjevná, ale nastíněná hypotéza vytváŕí vhodný teoretický rámec $\mathrm{k}$ diskusi. $\mathrm{V}$ důsledku tak činí mnohem přesvědčivěji než Durdíkova teorie hradi̊ prechodného typu i ve vztahu k podstatným lokalitám, jako je Týnec nad Sázavou (Durdík 2007). Validitu hypotézy naznačuje i podobná diskuse vedená nad britskými sídly typu burh-geat, která jsou nově považována za domácí předchůdce motte-and-bailey. Jde o valová opevnění se signifikantní stavbou brány, která často zahrnovala románské kostely a u kterých se stírá rozdíl mezi profánní a sakrální funkcí zástavby (Creighton 2012, 79-83). Podobnou funkční skladbu mají také falce v říšském prostředí, jakkoli jsou nesrovnatelné svým provedením (souhrnně Binding 1996). Nabízí se sledovat, zda se významně liší situace sídel v regionech, odkud známe původní vlastnické kostely v hojném počtu (napr. Benešovsko, Mostecko), a v těch oblastech, kde nám naopak víceméně chybí (např. širší Křivoklátsko).

Zaměření na dispoziční typologii z velké části zastínilo hlavní cíl studia sídel, kterým je pochopení jejich účelu v minulé společnosti. S dispozičními typy nelze $\mathrm{v}$ žádném prŕpadě spojovat konkrétní kategorie, které by původní společnost dokázala interpretovat a které by v ní byly jakkoli relevantní. Přesto je možné se o kategorizaci pokusit, vyjít je však třeba z odlišného základu, např́klad z potenciálu sídel naplňovat konkrétní funkce. Díky tomu je možné vydělit typy sice méně spojené s architektonickou formou sídla, nicméně lépe uchopitelné v procesu syntézy a interpretace. Na základě komplexního vyhodnocení byla proto v nedávné době navržena nová funkční klasifikace sídel na 1) neopevněné rezidence, 2) vymezující se rezidence (a - vymezené př́íkopem, b - ve vydělených polohách), 3) mocenské a reprezentační objekty (a - opevněné rezidence, $\mathrm{b}$ - mocenské opory), 4) opevněná správní centra, 5) občasné rezidenční objekty a 6) strážní objekty, k nimž lze vázat dílčí společenské úlohy, které taková sídla mohla plnit (více viz Novák 2019a). Tyto kategorie pak diachronně prostupují celým obdobím budování a užívání elitních sídel. Přestože vyžadují jistá formální a prostorová řešení, jejich konkrétní architektonické provedení se může odlišovat v závislosti na dobové technologii, individuálních preferencích i zázemí stavebníka. Pokud kupř́ikladu bylo cílem vrchnosti vymezit se vůči zbytku osídlení/ společnosti, je lhostejné, zda hranici mezi elitním a rurálním prostředím tvoří široký hradní př́kop a poloha na nedostupné ostrožně, nebo je to rozsáhlý zámecký park obehnaný ohradní zdí.

Pro taková témata archeologie zjevně přináší podstatně bohatší zjištění než historické narace, jmenovaný způsob uvažování bychom tak v důsledku měli přenášet na další třídy nálezů. Prostorové vztahy ve feudální společnosti byly natolik významné, že dovolují rekonstruovat kategorie symbolického myšlení a sociálních vazeb. V tom pozorujeme zřetelné rozdíly oproti prostřední prehistorických komunit, $v$ němž je společenské postavení obvykle nepřenosné a odvozované od sdílených společenských a kulturních zvyklostí (Květina et al. 2015, 108-133). Až nástup dědičně definovaných př́islušníků elity, vyjádřený pomocí erbovních znamení, dědičného postavení, šlechtických př́idomků, individuálních rodinných tradic, kumulací majetku a úředních funkcí (viz Šimůnek 2013, 137-327), dovolil užívat pregnantně vyjádřené stavební formy. K tomu samozřejmě přispěla i postupná specializace a dostupnost nových technologických řešení. Je tak prokazatelné, že rozvoj šlechtického myšlení byl nutně spojený s modernizací celé společnosti a urozený původ, rytířské tradice i reprezentace vlastní identity (srov. Vaníček 2007) determinovaly povahu a uzpůsobování sídelních forem. Přijetí tohoto faktu vrací český středověk zpět do okruhu společnosti západního ražení (ač na periferii jejího dosahu) s odpovídajícími důsledky. Především ale vrací archeologii středověku do kontaktu se současným historickým diskursem a společenskou diskusí. 


\section{Historická archeologie?}

Definice historické archeologie dosud stála na chronologickém vymezení (archeologie středověku) a výběru signifikantních archeologických kontextů a areálů, které byly argumentačně propojitelné s master narrativem českých dějin. Tím byly archeologické prameny částečně vědomě, částečně intuitivně kategorizovány do různých úrovní významnosti, která se ale míjí s jejich výpovědní hodnotou jako archeologického pramene. Historický diskurs se kupř́ikladu přímo odráží v pozornosti věnované dílčím lokalitám v množině raně středověkých hradišt'. To se odrazilo dokonce i v technickém a organizačním uspořádání archeologických institucí. Dominantní postavení hradišt' v diskusi o raném středověku mělo řadu dalších následků, mimo jiné hledání jejich př́mých pokračovatelů ve vrcholně stř̌edověkém světě. To formalisticky vyřešila definice hradu prechodného typu, který „potřeboval“ moderní badatel, ale nikoli středověká realita. Hlavní společenská funkce obou spojovaných sídelních forem přitom mohla být (a zřejmě i byla) zcela nespojitá. To se naopak nedá říci o celkovém vývoji, který v rozporu s dosud hojně přejímanými modely byl mnohem více evoluční a kontinuální.

Pokusili jsme se zde ilustrovat tendence podřídit strukturální rovinu pramenů o minulosti událostnímu výkladu. Archeologii pak přirozeně chybí kapacity při formulování a zodpovídání otázek, které by vykrývaly slepá místa historického vyprávění: nedovede dnes zodpovědět ani tak základní otázku, v jakém stavu se nacházela struktura hradišt' v české krajině pokročilého 11. a 12. století a jakou reálnou formu mělo majetkové a správní zázemí nejstarší pozemkové vrchnosti. Obdobně nedokáže tematizovat problematiku elit a jejich sídel v době přesahující období 16. století, i když pramenů pro takový výzkum rozhodně není nedostatek. Cesta k řešení nevede přes prosté rozšiřování pramenné báze. Primární data (často již dostupná!) na pramen informací totiž změní až inovovaný teoretický a metodologický rámec historické archeologie.

Posláním a povinností historické archeologie je proto překročit deficit v reflexi teorie a metody spojené se studiem historické narace a udržovat př́ímý kontakt se současnými otázkami historické vědy. Tím lze nalézt cestu ven z diskontinuit stanovených chronologicky, typologicky či tematicky. V tomto vztahu archeologie nutně nebude sekundantem historiků, ale díky přímému kontaktu získá možnost diskurs společně utvářet vykrýváním nespojitostí v poznání českých dějin. To dokáže nejen díky svébytné teoretické a metodické základně, spojené s poznáváním archeologických pramenů obecně, ale díky využití plného potenciálu artefaktů a ekofaktů jako všudypř́tomného informačního zdroje, který je zkreslován odlišnými faktory (formační procesy), než je typické pro psané prameny (subjektivní zkreslení).

Trhliny v českém diskursu lze zacelit jedině nastartováním procesu, který zahrnuje řadu souvisejících kroků. V první řadě jde o zpracování ucelené teorie historické archeologie, která se vypořádá se vztahem k ostatním oborovým paradigmatům, zvláště k chápání prehistorie, jež v nedávné době prodělalo značný vývoj. Je třeba soustavně rozvíjet metody práce s ,mimoarcheologickými“ pramennými kategoriemi, které ale nutně ovlivňují a rozšiřují možnosti nakládání $\mathrm{s}$ archeologickým materiálem, zejména ve fázi syntézy a interpretace. Takový základ je třeba položit v př́mém kontaktu s historiky, avšak bez snahy o jejich nahrazení v oblastech, které jsou jim vlastní. Navazovat by měla revize otázek, závěrů i tematických okruhů s cílem identifikovat klíčová témata odrážející současnou odbornou i společenskou diskusi. K pramenům je zároveň potřebné přristoupit konzistentně a pokrýt všechny chronologické, typové i prostorové rámce.

Pro takové kroky bude patrně nezbytné uvažovat též o přestavbě organizační struktury klíčových pracovišt'. V Archeologickém ústavu AV ČR v Praze by potřebnou změnu mohl přinést vznik Oddělení historické archeologie, které by integrovalo současné Oddělení archeologie středověku a dále rozšířilo jeho záběr. To by samozřejmě vyžadovalo i odpovídající personální rekonstrukci a přímé zapojení nearcheologických specialistů do činnosti oddělení (podobně jako jsou bez rozpaků do stavů zapojováni specialisté z př́írodovědných oborů). Podle našeho názoru se jedná o krok nevyhnutelný; organizační struktura české archeologie tak, jak byla postupně zformována $\mathrm{v}$ uplynulém století, prredpokládá výraznou úlohu centrálních institucí v podobě 
archeologických ústavů, jimž připadá komplexní odpovědnost za stav archeologického výzkumu nejen po stránce organizační, památkové či infrastrukturní, ale samozřejmě také teoretické. Je proto součástí úkolu Archeologického ústavu vytvářet konceptuální rámec nejen pro prominentní témata se silnou symbolickou hodnotou či aktuální v rámci společenského diskursu, ale pro celé spektrum pramenů, s nimiž se dnes archeologie - převážně tzv. záchranná - dennodenně setkává.

Finálním krokem je nastavení dialogu mezi vlastními a cizími narativy, at již jde o líčení specifická pro dílčí regiony, vycházející z různých oborů, dělená na základě chronologických celků, př́ípadně specifická pro různé tematické okruhy. K tomu může posloužit jedině sestavení skutečné korpusové práce historické archeologie v Čechách, obdoby Archeologie pravěkých Čech (Jiráň-Venclová 2008), avšak pro období středověku, novověku a moderní doby.

Publikační výstup vznikl za podpory projektu Archeologický informační systém České republiky - druhá generace (AIS-2; CZ.02.1.01/0.0/0.0/16_013/0001439).

\section{Prameny a literatura}

ALTHOFF, G., 2020: Rules and Rituals in Medieval Power Games: A German Perspective. Leiden.

AMČR: Archeologická mapa České republiky [online]. Dostupné z: http://www.archeologickamapa.cz/.

BARTOŠKOVÁ, A., 2014: Budeč. Významné mocenské centrum prvních Přemyslovců. Praha.

BIERBRAUER, V., 2004: Zur ethnischen Interpretationen in der frühgeschichtlichen Archäologie. In: Suche nach der Ursprüngen. Von den Bedeutung des frühen Mittelalters (Pohl, W., ed.), 45-84. Wien.

BINDING, G., 1996: Deutsche Königspfalzen: non Karl dem Großen bis Friedrich II. (765-1240). Darmstadt. BOHÁČOVÁ, I. et al., 2003: Stará Boleslav. Přemyslovský hrad v raném středověku. Praha.

BOHÁČOVÁ, I.-PODLISKA, J. et al., 2015: Průvodce pražskou archeologií. Památky známé, neznámé i skryté. Praha.

BOLINA, P.-CENDELÍN, D., 2014: „Ausgangspunkte“ - zur Methode der Altstraßenforschung. In: Tradition - Umgelstaltung - Innovation. Transformationsprozesse im hohen Mittelalter. Praehistorica 31/2 (Gringmuth-Dallmer, E.-Klápště, J., edd.), 743-755. Praha.

BOLINA, P.-KLIMEK, T.-CÍLEK, V., 2018: Staré cesty v krajině středních Čech. Praha.

BRATHER, S., 2004: Ethnische Interpretationen in der frühgeschichtlichen Archäologie. Geschichte, Grundlagen und Alternativen. Berlin.

BOOS, A., 1993: Die Ruine Flossenbürg: Auferstehung einer Burg des hohen und späten Mittelalters. Weiden.

BRATHER, S.-GEUENICH, D.-HUTH, C., 2009: Historia archaeologica. Festschrift für Heiko Steuer zum 70. Geburtstag. Berlin.

COLLINS, R., 2008: Die Fredegar-Chroniken. Hannover.

CREIGHTON, O., 2012: Early European Castles. Aristocracy and Authority, AD 800-1200. Bristol.

CURTA, F., 2009: The archaeology of service settlements in Eastern Europe. In: Central and Eastern Europe in the Middle Ages (Gorecki, P.-van Deusen, N., edd.), 30-41. London - New York.

ČECHURA, J., 2015: Sex v době temna. Sexuální život na českém jihu v prvním století Schwarzenberků (1660-1770). Praha.

DRAGOUN, Z. et al., 2002: Románské domy v Praze. Praha - Litomyšl.

DURDÍK, T., 2000: Nástin problematiky českých feudálních sídel 13. století, CB 7, 17-50.

- 2007: Hrady přechodného typu v Čechách. Praha.

- 2009: Ilustrovaná encyklopedie českých hradů. Praha.

- 2009a: Hrad Přimda. In: Mašek, M.-Sommer, P.-Žemlička, J. et al., Vladislav II., druhý král z Přemyslova rodu, 191-202. Praha.

DURDÍK, T.-BOLINA, P., 2001: Středověké hrady v Čechách a na Moravě. Praha.

FOUCALT, M., 1997: Der Mensch ist ein Erfahrungstier. Gespräch mit Ducio Trombadori. Frankfurt am Main. 
GADAMER, H.-G., 2010: Pravda a metoda I. Nárys filosofické hermeneutiky. Praha.

GRAUS, F., 1965: Raně středověké družiny a jejich význam při vzniku států ve střední Evropě, ČČH 13, $1-18$.

- 1980: Die Nationenbildung der Westslawen im Mittelalter. Sigmaringen.

GRUNWALD, S., 2019: Burgwallforschung in Sachsen. Ein Beitrag zur Wissenschaftsgeschichte der deutschen Prähistorischen Archäologie zwischen 1900 und 1961. Bonn.

GUREVIČ, A. J., 2008: Feudalismus před soudem historiků aneb o středověké „rolnické civilizaci“, Dějiny - teorie-kritika 1, 7-38.

HASIL, J., 2018: Chebsko v raném stř̌edověku. Archeologie středoevropského regionu v 7.-12. století. Praha. - v tisku: The Chronicle of the Czechs and its Spatial Structures: The Landscapes of Cosmas of Prague. In: Historiography and Identity V. Historiography and Identity in the New Europe, c. 1000-1300 (Pohl, W.Borri, F., edd.). Turnhout.

HASIL, J.-PROFANTOVÁ, N.-LEVÁ, K., 2020: Kovové artefakty jako klíč ke krajině a společnosti předpřemyslovských Čech, AH 45, 7-42.

HASIL, J.-ŠTEFAN, I., 2018: Eine Festung bei Prag: der frühmittelalterliche Burgwall in Prag-Královice. In: 50 Jahre Archäologie in Thunau am Kamp: Festschrift für Herwig Friesinger (Nowotny, E.-Obenaus, M.Uzunoglu-Obenaus, S., edd.), 202-218. Krems.

HASIL, J.-VAN RENSVOUDE, I., 2019: Introduction. In: Cosmae Pragensis Chronica Bohemorum - Cosmas of Prague. The Chronicle of the Czechs (Bak, J. M.-Rychterová, P., edd.), X-LIX. Budapest - New York.

HECHBERGER, W., 2005: Adel im fränkisch-deutschen Mittelalter. Zur Anatomie eines Forschungsproblems. Stuttgart.

CHARVÁT, P., 1987: K otázce soukromého vlastnictví půdy na Velké Moravě, AR XXXIX, 672-679.

JAN, L., 2000: Vznik zemského soudu a správa Moravy. Brno.

- 2007: Dominium generale a dominium speciale - jeden mýtus české historiografie. In: Inter laurum et olivam (Šouša, J.-Ebelová, I., edd.), 645-652. Praha.

- 2007a: Skrytý půvab „středoevropského modelu“, ČČH 105, 873-902.

- 2007b: K počátkům české šlechty. Družina, beneficium, pozemkové vlastnictví. In: Šlechta, moc a reprezentace ve středověku (Nodl, M.-Wihoda, M., edd.), 45-52. Praha.

- 2009: Hereditas, výsluha, kastelánie. Několik poznámek k terminologii a metodologii současné historiografie přemyslovského období, ČMM CXXVIII, 461-472.

- 2015: Co byla beneficia a beneficiáři v přemyslovské monarchii? In: X. sjezd českých historiků. Sv. 6 (Zářický, A.-Kadlec, P.-Závodná, M., edd.), 45-51. Ostrava.

JUROK, J., 2000: Česká šlechta a feudalita ve středověku a raném novověku. Majetková a sociální struktura, politická moc a kulturní reprezentace šlechty a feudality v českém státě ve 13. - první polovině 17 . století. Nový Jičín.

KALHOUS, D., 2011-2013: České země za prvních Přemyslovců v 10.-12. století. Praha.

- 2018: Creating bonds, creating memories. Monasteries Kladruby and Opatovice in twelfth century and their forgeries, Studia historica Brunensia 65, 38-50.

KARBUSICKÝ, V., 1980: Anfänge der historischen Überlieferung in Böhmen. Ein Beitrag zum vergleichenden Studium der mittelalterlichen Sängerepen. Köln.

KLÁPŠTĚ, J., 2003: Dějepis a archeologie: příbuzenství jak se patří. In: Dějiny ve věku nejistot (Klápště, J.Plešková, E.-Žemlička, J., edd.), 96-109. Praha.

- 2005: Proměna českých zemí ve středověku. Praha.

- 2012: Adel, Burg und Herrschaft - eine ewig strittige Problematik der tschechischen Mediävistik? In: Adel, Burg und Herrschaft an der „Grenze“. Österreich und Böhmen (Birngruber, K.-Schmid, C., edd.), 225-238. Linz.

KOLEKTIV 1998-2005: Encyklopedie českých tvrzí. Praha.

KOVÁ ̌̌, D., 2011: Tvrze, hrady a zámky Českobudějovicka. České Budějovice.

KUBEŠ, J., 2008: Vývoj obytné jednotky v sídlech vyšši šlechty z českých zemí (1550-1750), Svorník 6, $79-90$. 
KUBU゚, F., 1997: Štaufská ministerialita na Chebsku. Cheb.

KUNA, M. et al., 2014: Archeologický atlas Čech. Vybrané památky od pravěku do 20. století. Praha.

KVĚTINA, P. et al., 2015: Minulost, kterou nikdo nezapsal. Červený Kostelec.

LAVAL, F., 2013: Archeologie tvrze v českých zemích. K počátkům středověkých opevněných sídel. Rkp. disertační práce, Ústav pro archeologii, FF UK v Praze.

- 2016: Co je kostel? K počátkům šlechtických sídel českého středověku, AR LXVIII, 47-90.

MACEK, J., 1997: Česká stř̌edověká šlechta. Praha.

MACHÁČEK, J., 2005: Raně středověké Pohansko u Břeclavi: munitio, palatium, nebo emporium moravských panovníků?, AR LVII, 100-138.

- 2008: Středoevropský model a jeho archeologické testování, ČČH 106, 598-626.

MEDUNA, P., 2009: Curia Radonice - výjimka nebo pravidlo? Stručné zamyšlení nad knížecími dvory v raném středověku. In: Mašek, M.-Sommer, P.-Žemlička, J., et al., Vladislav II., druhý král z Přemyslova rodu, 203-211. Praha.

MENCLOVÁ, D., 1976: České hrady. Praha.

NEUSTUPNÝ, E., 2010: Teorie archeologie. Plzeň.

NODL, M., 2007: Pozdně středověká transformace Kosmova mýtu o počátcích práv a zákonů kmene Čechů. Kronikáři dvorského okruhu, Maiestas Carolina, Ondřej z Dubé a Viktorin Kornel ze Všehrd. In: Šlechta, moc a reprezentace ve středověku (Nodl, M.-Wihoda, M., edd.), 189-207. Praha.

NOVÁČEK, K. et al., 2010: Kladrubský klášter 1115-1421. Osídlení - architektura - artefakty. Plzeň.

NOVÁK, D., 2019: Současné otázky evropské kastelologie a jejich reflexe v českém prostředí - Aktuelle Fragen der europäischen Burgenkunde und ihre Reflexion in Tschechien, AH 44, 7-27.

- 2019a: Funkční klasifikace a vývoj vrchnostenských sídel ve středověkých a raně novověkých Čechách, PA CX, 307-382.

NOVOTNÝ, R., 2007: Úloha zemského soudu pro formování panského stavu. In: Šlechta, moc a reprezentace ve středověku (Nodl, M.-Wihoda, M., edd.), 241-250. Praha.

PATZOLD, S., 2012: Das Lehnswesen. München.

PETRÁČEK, T., 2012: Nevolníci a svobodní, kníže a velkostatek. Fenomén darovaných lidí přemyslovských zemí 10.-12. století. Praha.

PETRÁŇ, J., 1976: Skladba pohusitské aristokracie v Čechách. Úvod do diskuse. In: Proměny feudální tř́idy v Čechách v pozdním feudalismu. Acta Universitatis Carolinae, Philosophica et historica 1 (Petráň, J., ed.), 9-80. Praha.

PETRÁŇ, J. et al., 1985-1997: Dějiny hmotné kultury. Praha.

PROFANTOVÁ, N., 2000: Slovanské výšinné sídliště z Třebovle, okr. Kolín. K problému napodobení cizích předloh v keramice, AR LII, 647-664.

- 2017: New data about the earliest of Early Medieval hill-forts and hill-sites (8-1st half of 9th cent) in central

Bohemia. In: Archäologische Studien zum frühen Mittelalter (Fusek, G., ed.), 99-114. Nitra.

- v tisku: Avar Type Finds in Bohemia and the Traces of its Local Production. In: Two Sides of a Belt Strap End. Avars on the north and south of the Kaghanate. Zagreb.

PROFANTOVÁ, N.-PROFANT, M., 2003: Archeologie a historie aneb ,jak vykopávat“ dějiny? In: Dějiny ve věku nejistot (Klápště, J.-Plešková, E.-Žemlička, J., edd.), 239-250. Praha.

PROFANTOVÁ, N.-TOMKOVÁ, K., 2018: Strongholds and material culture of the Bohemian elite in the Early Přemyslid period. In: Kouřil, P.-Procházka, R., et al., Moravian and Silesian strongholds of the tenth and eleventh centuries in the context of Central Europe, 261-282. Brno.

PROFANTOVÁ, N. et al., 2010-2015: Klecany. Raně středověká pohřebiště. Praha.

PROCHÁZKA, M., 2008: 75 let od výzkumu tvrze Královice, ASČ 12, 767-772.

RAZÍM, V., 2004: Nad počátky hradů české šlechty, AR LVI, 176-214.

ROGERS, E., 1983: Diffusion of Innovations. New York.

RUDOLF, T., 1957: Die frühmittelalterlichen Stämmegebiete in Böhmen. Praha.

- 1982: Čechy v raném středověku. Praha.

RYKL, M., 2008: Obytná část dispozice středověké tvrze v Čechách, Svorník 6, 33-68.

SEDLÁČEK, A., 1882-1927: Hrady, zámky a tvrze Království českého. Praha. 
SLÁMA, J., 1986: Střední Čechy v raném středověku 2. Hradiště, př́ispěvky k jejich dějinám a významu. Praha.

- 1987: K počátkům hradské organizace v Čechách. In: Typologie raně feudálních slovanských států (Žemlička, J., ed.), 175-190. Praha.

- 1989: Střední Čechy v raném středověku 3. Archeologie o počátcích přemyslovského státu. Praha.

- 2003: Kosmovy záměrné omyly. In: Dějiny ve věku nejistot (Klápště, J.-Plešková, E.-Žemlička, J., edd.), 261-267. Praha.

SMETÁNKA, Z., 2015: Dva domy v jiřské ulici a jeden v podhradí. Ze vzpomínek a rozpomínek na proměny archeologie středověku. In: Středověká Evropa v pohybu. K poctě Jana Klápště (Boháčová, I.Sommer, P., edd.), 503-521. Praha.

STEPHAN, H.-G., 2010: Der Solling im Mittelalter. Archäologie - Landschaft - Geschichte im Weser- und Leinebergland. Siedlungs- und Kulturlandschaftsentwicklung. Die Grafen von Dassel und Nienover. Dormagen.

STEUER, H., 1997: Waagen und Gewichte aus dem mittelalterlichen Schleswig. Funde des 11. bis 13. Jahrhunderts aus Europa als Quellen zur Handels- und Währungsgeschichte. Köln.

ŠIMŮNEK, R., 2013: Reprezentace české středověké šlechty. Praha.

ŠOLLE, M., 1984: Staroslovanské hradisko: charakteristika, funkce, vývoj a význam. Praha.

ŠTEFAN, I., 2011: Great Moravia, statehood and archaeology: the "decline and fall" of one early medieval polity. In: Frühgeschichtliche Zentralorte in Mitteleuropa. Internationale Konferenz und Kolleg der Alexander von Humboldt-Stiftung zum 50. Jahrestag des Beginns archäologischer Ausgrabungen in Pohansko bei Břeclav (Macháček, J.-Ungerman, Š., edd.), 333-354. Bonn.

- 2019: Č́ je ta krajina? Rozhovory s Janem Klápště o středověku i našem světě. Praha.

TOMÁŠEK, M. et al., 2015: 100 zajímavých archeologických lokalit Moravy a Slezska. Praha - Brno.

TŘEŠTÍK, D., 1971: K sociální struktuře přemyslovských Čech. Kosmas o knížecím vlastnictví půdy a lidí, ČC̆H 19, 537-567.

- 2001: Vznik Velké Moravy. Praha.

- 2001a: K poměru archeologie a historie, AR LIII, 357-361.

TŘEŠTÍK, D.-ŽEMLIČKA, J., 2007: O modelech vývoje přemyslovského státu, ČČH 105, 122-164.

ÚLOVEC, J., 1998: Hrady, zámky a tvrze na Chebsku. Cheb.

VANÍČEK, V., 1994: Strukturální proměny české státnosti ve starším středověku. In: VII. sjezd českých historiků, 127-151. Praha.

- 2003: Strukturální vývoj sociálních elit v českých zemích do roku 1310 (Základní vývojové tendence metodologické souvislosti). In: Genealogia. Stan i perspektywy badań nad spoleczeństwem Polski średniowiecznej ne tle porównawczym (Pakulski, J.-Wroniszewski, J., edd.), 233-300. Toruń.

-2007: Sociální mentalita české šlechty: urozenost, rytî́ství, reprezentace (Obecné souvislosti, pojetí družiny, „,modernizačni“ trend). In: Šlechta, moc a reprezentace ve středověku (Nodl, M.-Wihoda, M., edd.), 141-188. Praha.

- 2011: „Středověká modernizace“ jako koncept strukturální proměny pro středovýchodní Evropu. In: Dynamika przemian społecznych i religijnych w średniowieczu (Grabarczyk, T.-Nowak, T., edd.), 11-37. Warszawa.

- 2015: Paradoxy marxistické medievistiky z pohledu současnosti (koncept státotvorné družiny raného středověku v české a německé historiografii). In: X. sjezd českých historiků. Svazek IV (Tářický, A.-Kadlec, P.-Závodná, M., edd.), 13-39. Ostrava.

VARADZIN, L., 2010: K vývoji hradišt’ v jádru Čech se zřetelem $\mathrm{k}$ přemyslovské doméně (příspěvek do diskuse), AR LXII, 535-554.

VAŠÍČEK, Z., 2006: Archeologie, historie, minulost. Praha.

VYKYPĚL, B., 2004: Studie k šlechtickým titulům v germánských, slovanských a baltských jazycích. Etymologie jako pomocná věda historická. Brno.

WEST, C., 2013: Reframing the Feudal Revolution. Political and Social Transformation Between Marne and Moselle, c. 800 - c. 1100. Cambridge.

WIHODA, M., 2007: Kníže a jeho věrní. Kosmas o světě předáků a urozených. In: Šlechta, moc a reprezentace ve středověku (Nodl, M.-Wihoda, M., edd.), 9-29. Praha. 
ZELENKA, J., 2016: Beneficium et feudum. Podoba a proměny lenního institutu. Praha.

ŽEMLIČKA, J., 2003: České 13. století: „privatizace“ státu, ČČH 101, 509-540.

- 2009: O „svobodné soukromosti“ pozemkového vlastnictví (K rozsahu a kvalitě velmožské držby v přemyslovských Čechách), ČČH 107, 269-308.

- 2012: K pozemkové výbavě české nobility ve starším středověku, ČČH 110, 189-233.

- 2016: „Dvacet pánư“ české země (k vymezení panujícího rodu v 11. a 12. století), ČMM CXVII, 293-309.

\section{Zusammenfassung}

\section{Diskontinuitäten der historischen Archäologie in Tschechien? Einige Anmerkungen zum Studium mittelalterlicher Eliten}

Die tschechische Mittelalterarchäologie hat als Empfänger des historischen Narrativs einen geschlossenen Umschlag von arbiträr gewählten Themen geschaffen, die zum Bestandteil eines Diskurses geworden sind, was auch eine Menge von ausgeschlossenen Themen mit sich brachte. Ihnen hat man über Generationen hinweg das Sammeln und Sortieren von Quellen untergeordnet, sodass es bei vielen ihrer Kategorien - die oftmals mit der Frage der Erforschung von Eliten und ihren Sitzen zusammenhängen - heute kaum möglich ist, eine Diskussion mit historischem Narrativ zu eröffnen, da die Archäologie mit den verfügbaren Quellen keine Alternative dazu schafft. Einerseits ist eine solche Vorgehensweise völlig legitim in Zeiten, als die Archäologie eine für sie völlig neue Umgebung betrat (slawische Archäologie im 19. Jahrhundert, Formierung der Archäologie des jüngeren Mittelalters u.ä.), nichtsdestotrotz handelt es sich unserer Meinung nach um keine dauerhafte Paradigmengrundlage der historischen Archäologie. Das gegenwärtige Ergebnis dieses Ansatzes betrachten wir als kontrovers: einerseits verfügt die tschechische Archäologie des Mittelalters über einen durchgearbeiteten Interpretationsrahmen, der es ihr ermöglichte, den überwiegenden Teil der Erscheinungen zu thematisieren, denen sie begegnet, bzw. mit denen sie sich aktiv beschäftigen will. Das Problem dabei ist jedoch, dass dieser Ansatz nicht auf andere Regionen bzw. Zeiträume übertragen werden kann sowie eine innere Instabilität - die Rezeption historischer Narrativen stellt einen iterativen und niemals endenden Prozess dar, auf die kein stabiles Fachparadigma aufgebaut werden kann.

Die Definition der historischen Archäologie gründete sich bisher auf eine chronologische Abgrenzung (Archäologie des Mittelalters) und auf eine Auswahl signifikanter archäologischer Kontexte und Areale, die argumentationsmäßig mit dem master narrative der tschechischen Geschichte verknüpfbar waren. Dadurch wurden die archäologischen Quellen teils bewusst, teils intuitiv in verschiedene Bedeutungsebenen kategorisiert, die ihren Aussagewert als archäologische Quelle jedoch verfehlen. Der historische Diskurs spiegelt sich beispielsweise in der Aufmerksamkeit wider, die man Teilfundstellen in der Menge von frühmittelalterlichen Burgwällen entgegengebracht hat. Das spiegelte sich sogar auch in der technischen und organisatorischen Struktur der archäologischen Institutionen wider. In Tschechien existieren offensichtliche Tendenzen, die strukturelle Ebene der Vergangenheit einer Ereignisinterpretation unterzuordnen. Der Archäologie fehlen dann natürlich Kapazitäten bei der Formulierung und Beantwortung von Fragen, die weiße Stellen des historischen Narrativs abdecken würden: sie vermag heute keine Antwort auf die noch nicht einmal so grundsätzliche Frage zu geben, wie etwa in welchem $\mathrm{Zu}$ stand sich die Struktur der Burgwälle in der böhmischen Landschaft des fortgeschrittenen 11. und 12. Jahrhunderts befand oder welche reale Form das besitz- und verwaltungsmäßige Umfeld der ältesten Grundobrigkeit hatte. Analog dazu vermag sie nicht die Problematik der Eliten und ihrer Sitze in der Zeit zu thematisieren, die über die Zeit des 16. Jahrhunderts hinausreicht, obwohl es für eine solche Untersuchung an Quellen eindeutig nicht mangelt.

Deshalb ist es für die historische Archäologie Berufung und Pflicht, das Defizit in der Reflexion der Theorie und Methode in Verbindung mit einem Studium der historischen Narration 
zu überwinden und direkten Kontakt mit den aktuellen Fragen der historischen Wissenschaften zu unterhalten. Die Risse im tschechischen Diskurs können einzig durch die Ingangsetzung eines Prozesses geschlossen werden, der eine Reihe miteinander zusammenhängender Schritte umfasst. In erster Linie geht es um die Ausarbeitung einer in sich geschlossenen Theorie der historischen Archäologie, die sich mit dem Bezug zu den übrigen fachlichen Paradigmata auseinandersetzt, besonders zur Archäologie der Vorgeschichtszeit. Es müssen systematisch Methoden der Arbeit mit „außerarchäologischen“ Quellenkategorien entwickelt werden, die zwangsläufig jedoch die Möglichkeiten des Umgangs mit dem archäologischen Material erweitern und beeinflussen, besonders in der Phase von Synthesen und Interpretationen. Eine solche Grundlage muss in direktem Kontakt mit den Historikern geschaffen werden, jedoch ohne das Bestreben, sie in Bereichen zu ersetzen, die ihnen eigen sind. Daran anschließen sollte eine Revision der Fragen, Schlussfolgerungen und Themenkreise, mit dem Ziel, die Schlüsselthemen zu identifizieren, welche die gegenwärtige gesellschaftliche Diskussion widerspiegeln. An die Quellen muss man gleichzeitig konsistent herangehen, wobei alle chronologischen Rahmen- und Typeneingrenzungen abgedeckt werden sollten.

Für solche Schritte wird es vermutlich auch unvermeidbar sein, einen Umbau der Organisationsstrukturen der Schlüsselarbeitsstätten in Erwägung zu ziehen. Am Archäologischen Institut der Akademie der Wissenschaften der Tschechischen Republik in Prag (ARÚ) könnte die notwendige Veränderung die Entstehung einer Abteilung für historische Archäologie mit sich bringen. Dies würde selbstverständlich auch einen entsprechenden personellen Umbau und eine direkte Einbindung von nicht archäologischen Experten in die Tätigkeit der Abteilung erforderlich machen. Bestandteil der Aufgabe des ARÚ ist die Schaffung eines konzeptuellen Rahmens nicht nur für prominente Themen mit starkem symbolischen Wert, bzw. die im Rahmen des gesellschaftlichen Diskurses aktuell sind, sondern für das gesamte Quellenspektrum, denen die Archäologie - vornehmlich die sog. Rettungsarchäologie - tagtäglich begegnet. Der finale Schritt ist die Abstimmung des Dialogs zwischen eigenen und fremden Narrativen, gleich, ob es sich dabei um die Schilderung von auf verschiedenen Fachgebieten basierenden, anhand von chronologischen Einheiten unterteilten Spezifika für Teilregionen, oder ggf. um Spezifika für verschiedene Themenkreise handelt. Dazu kann einzig und allein die Erstellung wirklicher Korpusarbeiten der historischen Archäologie in Tschechien dienen, einer Entsprechung der bereits vorliegenden Archäologie des urzeitlichen Böhmens, jedoch für die Zeit des Mittelalters, der Neuzeit und der Moderne.

Der vorliegende Publikationsbeitrag entstand unter Förderung des Projektes Das archäologische Informationssystem der Tschechischen Republik - zweite Generation (AIS-2; CZ.02.1.01/0.0/0.0/16_013/0001439).

Mgr. Jan Hasil, Ph.D., Archeologický ústav AV ČR, Praha, v. v. i., Letenská 4, 11801 Praha 1, Česká republika,hasil@arup.cas.cz

Mgr. David Novák, Ph.D., Archeologický ústav AV ČR, Praha, v. v. i., Letenská 4, 11801 Praha 1, Česká republika,novak@arup.cas.cz 
